4 Yi Wu, ${ }^{1,2,7}$ Yanqiong Shen, ${ }^{2,7}$ Namei Wu, ${ }^{1,2,7}$ Xinghai Zhang, ${ }^{3,7}$ Shaohong Chen, ${ }^{3,4}$ 5 Chang Yang, ${ }^{1,2}$ Junhui Zhou, ${ }^{3,4}$ Yan Wu, ${ }^{3}$ Da Chen, ${ }^{5}$ Li Wang, ${ }^{2}$ Yuye Wang, ${ }^{6}$ Jiejie Xu, ${ }^{6}$ 6 Ke Liu, ${ }^{6}$ Chao Wang, ${ }^{5}$ Huajun Zhang, ${ }^{3, *}$ Ninuo Xia, ${ }^{2, *}$ Sandra Chiu, ${ }^{2, *}$ and

7 Yucai Wang ${ }^{1,2,6,8, *}$

$8 \quad{ }^{1}$ Department of Radiology, The First Affiliated Hospital of USTC, Division of Life

9 Sciences and Medicine, University of Science and Technology of China, Hefei 230001,

\section{Omicron-specific mRNA vaccine elicits potent immune responses in mice, hamsters, and nonhuman primates}

\author{
P. R. China
}

${ }^{2}$ School of Basic Medical Sciences, Division of Life Sciences and Medicine, University of Science and Technology of China, Hefei 230027, P. R. China

${ }^{3}$ State Key Laboratory of Virology, Wuhan Institute of Virology, Center for Biosafety Mega-Science, Chinese Academy of Sciences, Wuhan 430062, P. R. China

${ }^{4}$ University of Chinese Academy of Sciences, Beijing 100049, P. R. China

${ }^{5}$ MOE Key Laboratory for Cellular Dynamics, School of Life Sciences, Division of Life Sciences and Medicine, University of Science and Technology of China, Hefei 230027, P. R. China

${ }^{6}$ RNAlfa Biotech, Hefei 230088, P. R. China

${ }^{7}$ These authors contributed equally to this work

${ }^{8}$ Lead Contact

*Corresponding author: hjzhang@wh.iov.cn (H.-J.Z.), nxia007@ustc.edu.cn (N.-N.X.), qiux@ustc.edu.cn (S.C.), yucaiwang@ustc.edu.cn (Y.-C.W.) 


\section{ABSTRACT}

SARS-CoV-2 has infected more than 400 million people around the globe and caused millions of deaths. Since its identification in November 2021, Omicron, a highly transmissible variant, has become the dominant variant in most countries. Omicron's highly mutated spike protein, the main target of vaccine development, significantly compromises the immune protection from current vaccination. We develop an mRNA

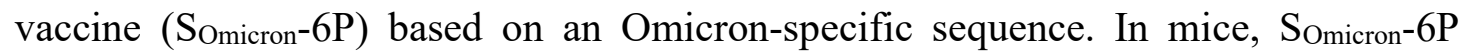
shows superior neutralizing antibodies inducing abilities to a clinically approved inactivated virus vaccine, a clinically approved protein subunit vaccine, and an mRNA vaccine $\left(\mathrm{S}_{\mathrm{WT}}-2 \mathrm{P}\right)$ with the same sequence of BNT162b2 RNA. Significantly, $\mathrm{S}_{\text {Omicron- }}$ 6P induces a 14.4 27.7-fold and a 28.3 50.3-fold increase of neutralizing activity against the pseudovirus of Omicron and authentic Omicron compared to $\mathrm{S}_{\mathrm{WT}}-2 \mathrm{P}$, respectively. In addition, two doses $\mathrm{S}_{\text {Omicron-6P }}$ significantly protects Syrian hamsters against challenge with SARS-CoV-2 Omicron variant and elicits high titers of nAbs in a dose-dependent manner in macaques. Our results suggest that SOmicron-6P offers advantages over current vaccines, and it will be helpful for those with weak immunity. 


\section{INTRODUCTION}

Severe acute respiratory syndrome coronavirus 2 (SARS-CoV-2) has infected more than 400 million people around the globe and caused several million deaths (Koh et al., 2021; Vogel et al., 2021). Since its discovery in November 2021, SARS-CoV-2 variant B.1.1.529, the World Health Organization (WHO) designation “Omicron”, has quickly spread and become dominant (Karim and Karim, 2021). The Omicron variant is highly transmissible and can infect human more quickly than other variants (Suzuki et al., 2022). Omicron currently represents $\sim 99 \%$ of the new infections in the US, Europe, and other major countries (www.gisaid.org/hcov19-variants/).

The Omicron variant carries approximately 30 mutations, some of which help it to escape the majority of existing SARS-CoV-2 neutralizing antibodies (nAbs) (Cao et al., 2021; Dejnirattisai et al., 2022a; Flemming, 2022; Planas et al., 2021). Most spike (S) protein monoclonal antibodies could no longer neutralize the Omicron variant. Convalescent individuals previously infected with other variants have little nAbs against Omicron and can be re-infected (Cele et al., 2021; Sun et al., 2022). Several studies show that the Omicron variant significantly weakened or knocked out the protection conferred by two vaccine doses. After a vaccine booster shot, vaccinees' sera (post-vaccination sera) show enhanced nAb titers but are still around 20-fold less potent in neutralizing the Omicron variant than other variants (Hu et al., 2022; Liu et al., 2022;

Planas et al., 2021; VanBlargan et al., 2022).

On the bright side, the third dose of current major vaccines significantly reduced the risk of hospitalization, severe illness, and death caused by Omicron. The Centers 
64

65

66

67

68

69

70

71

for Disease Control and Prevention (CDC) of America reported that a third vaccination prevented Omicron infected people from emergency room visits or urgent care with $82 \%$ and 90\% effectiveness, respectively (Pia and Rowland-Jones, 2022; Thompson et al., 2021). However, for those with disadvantages, such as old age, pre-existing conditions, or being vaccinated with less potent vaccines, Omicron still poses a considerable threat. A recent phase 4 clinical trial in Brazil indicates a significant fraction of people who received three doses still have Omicron neutralization titers lower or barely above the limit to be considered seropositive (Malik et al., 2022; Mistry et al., 2021). Thus, an Omicron effective vaccine is urgently needed. Here we develop an Omicron variant sequence-based mRNA vaccine which is much more potent in inducing nAbs in multiple animal models against Omicron challenge than the original wild-type mRNA vaccine, inactivated virus vaccine, and protein subunit vaccine, and importantly, provides complete protection in hamster model at the dose as low as $1 \mu \mathrm{g}$. 


\section{RESULTS}

For full-length Omicron-specific mRNA vaccine design (named SOmicron-6P), we adopted the "hexapro" spike protein sequence as the backbone for its enhanced stability of prefusion conformation and substituted the respective sequences with the Omicron mutations (Table S1) (Hsieh et al., 2020). Modified Omicron mRNA was synthesized with high purity through in vitro transcription (Figure S1A). Robust expression of Omicron spike protein on HEK293T cell surface was detected after transfection with immunofluorescence (Figure S1B). The mRNA was then encapsulated into even-sized lipid nanoparticles (LNP) to generate the final vaccine product, SOmicron-6P, whose size is $110 \mathrm{~nm}$ on average (Figure S1C). We adopted the BNT162b2 RNA sequence with the two proline mutations as the control mRNA vaccine ( $\left.\mathrm{S}_{\mathrm{WT}}-2 \mathrm{P}\right)$ (Vogel et al., 2021).

We first tested the humoral responses to the immunogenicity of the vaccine. Mice

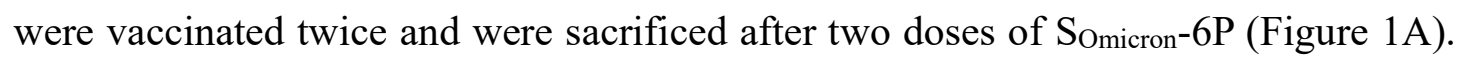
We observed a significant increase in both total B cells $\left(\mathrm{CD} 19^{+}\right)$and plasma B cells $\left(\mathrm{CD} 138^{+} \mathrm{B} 220^{-}\right)$in the spleens of SOmicron-6P immunized mice (Figure 1B and 1C), indicating $\mathrm{S}_{\text {Omicron-6P can induce B cell responses. Then we performed a head-to-head }}$ comparison of $\mathrm{S}_{\text {Omicron-6P versus }} \mathrm{S}_{\mathrm{WT}}-2 \mathrm{P}$, along with two clinically approved vaccines, one inactivated virus vaccine, and one protein subunit vaccine, on immunogenicity in $\mathrm{BALB} / \mathrm{c}$ mice. Mice were vaccinated twice at various doses of each vaccine, and antibodies in the sera were measured one week after the second vaccination (Figure 1A). The antigen-specific IgG geometric mean titers (GMTs) were measured against Omicron Spike trimer protein with ELISA (Figure 1D and S2). Both SOmicron-6P and 
$100 \mathrm{~S}_{\mathrm{WT}}-2 \mathrm{P}$ elicited $\mathrm{IgG}$ antibodies in a dose-dependent manner. At 5 and $10 \mu \mathrm{g}$ dose levels,

101 SOmicron-6P induced significantly higher IgG than $\mathrm{S}_{\mathrm{WT}}-2 \mathrm{P}$, by 1.8 -and 2.3 -fold,

102 respectively. The entry inhibition by serum of immunized mice was measured in a

103 neutralization assay using vesicular stomatitis virus (VSV)-based Omicron pseudovirus.

104 Dramatically but not surprisingly, the Somicron-6P vaccinated mice elicited 14.4 27.8-

105 fold higher serum neutralizing activity than those by $\mathrm{S}_{\mathrm{WT}}-2 \mathrm{P}$ at all three dose groups

106 (Figure 1E and S3-S4). Next, 50\% virus-neutralization GMTs were measured by an

107 Omicron-neutralization assay. As expected, 28.3 50.3-fold higher neutralizing titers

108 were observed from mice immunized with SOmicron-6P than those immunized with SwT-

$1092 \mathrm{P}$, using a plaque reduction neutralization test with authentic Omicron (Figure 1F). By

110 contrast, two doses of immunization using inactivated virus vaccine or protein subunit

111 vaccine hardly induced any Omicron nAbs in mice (Figure 1E-1F and S5-S6). These

112 results suggest that $\mathrm{S}_{\text {Omicron-6P }}$ is potent in inducing Omicron-specific antibodies. 
bioRxiv preprint doi: https://doi.org/10.1101/2022.03 01.481391; this version posted March 1, 2022. The copyright holder for this preprint (which was not certified by peer review) is the author/funder, who has granted bioRxiv a license to display the preprint in perpetuity. It is made available under aCC-BY-NC-ND 4.0 International license.

A

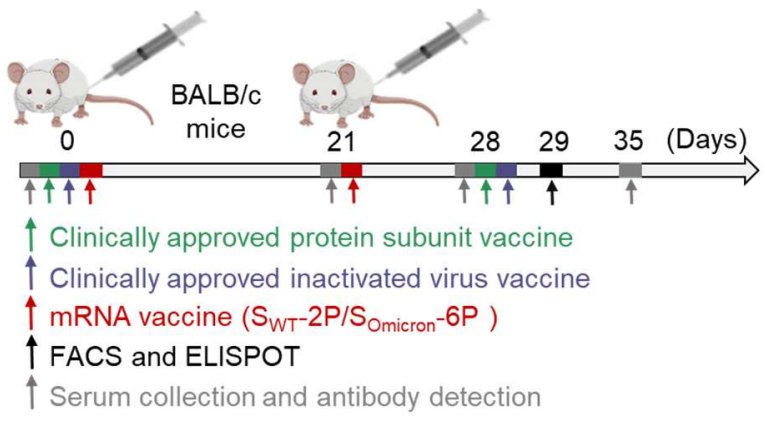

B

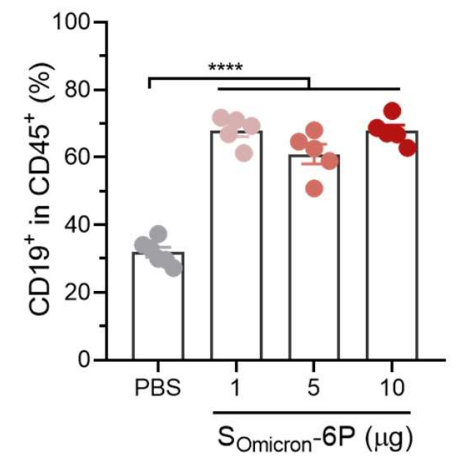

C

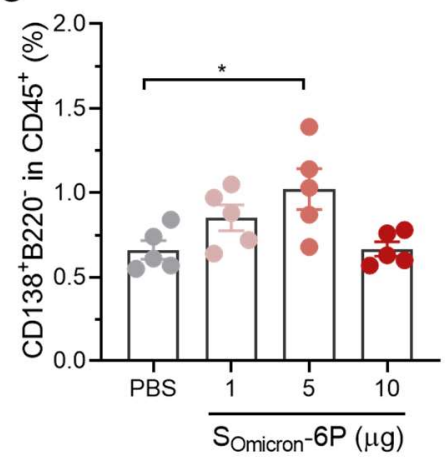

D 1 week after 2nd vaccination

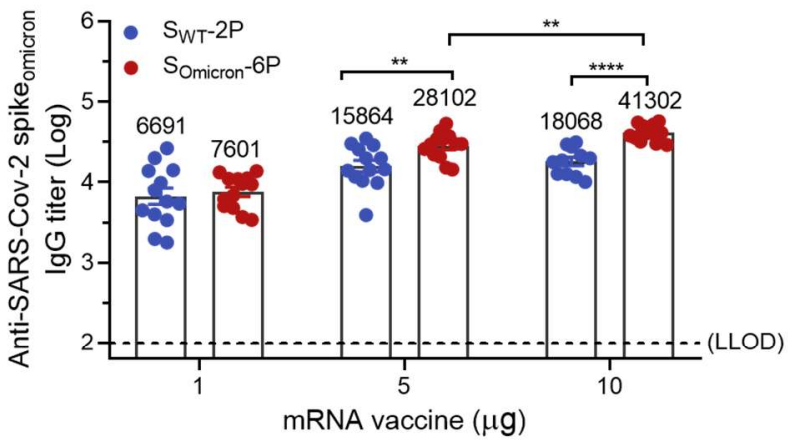

E

1 week after 2 nd vaccination

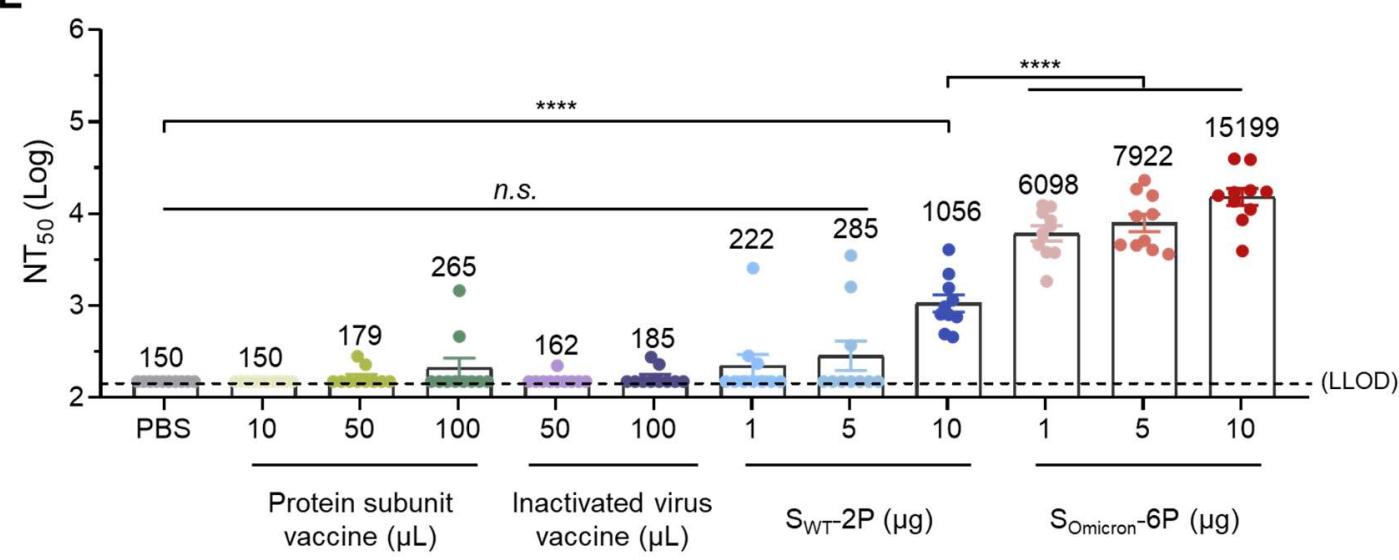

$\mathbf{F}$

1 week after 2 nd vaccination

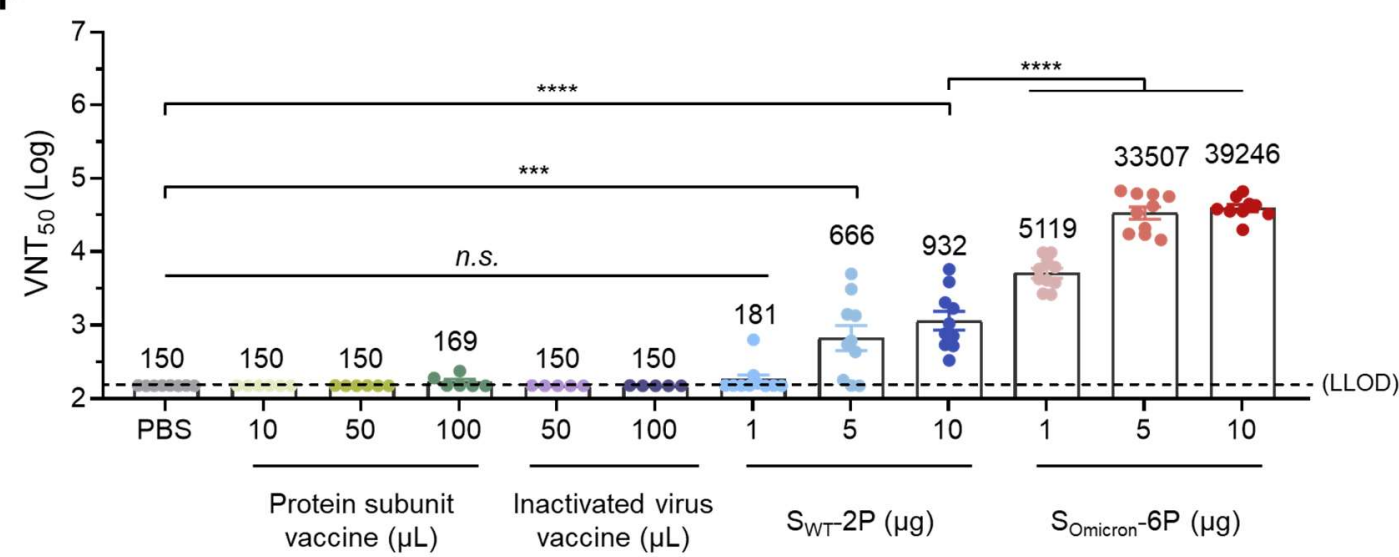



Mice.

(A) Schematic diagram of immunization and sample collection schedule in mice. Female BALB/c mice were immunized on a two-dose schedule with $\mathrm{S}_{\mathrm{WT}}-2 \mathrm{P}$, SOmicron$6 \mathrm{P}$, protein subunit vaccine using a dimeric form of the receptor-binding domain of wild-type SARS-CoV-2, or inactivated vaccine of wild-type SARS-CoV-2. (B-C) Percentages of (B) B cells and (C) plasma cells in spleen after immunized with different doses of SOmicron-6P.

(D) The Omicron SARS-CoV-2 variant specific IgG antibody titers were determined by ELISA (lower limit of detection $($ LLOD) $=100)$.

(E) Neutralization titers $\left(\mathrm{NT}_{50}\right)$ were determined by recombinant vesicular stomatitis virus (VSV)-based pseudovirus (Omicron variant) neutralization assay (LLOD $=150)$. (F) SARS-CoV-2 Omicron 50\% virus-neutralization titers $\left(\mathrm{VNT}_{50}\right)$ were determined by a plaque reduction neutralization test $(\mathrm{LLOD}=150)$.

Data are shown as mean \pm SEM. Significance was calculated using one-way ANOVA with multiple comparisons tests (n.s., not significant, ${ }^{*} \mathrm{p}<0.05, * * \mathrm{p}<0.01,{ }^{* * *} \mathrm{p}<$ $0.001, * * * * p<0.0001)$ For $\mathrm{T}$ cell analysis in spleens, although the ratios of $\mathrm{CD}^{+}$and $\mathrm{CD} 8^{+} \mathrm{T}$ cells within $\mathrm{CD} 45^{+}$leukocytes remain unchanged, Somicron-6P elicited significant increases in activated $\mathrm{CD}^{+}\left(\mathrm{CD}^{+} 9^{+} \mathrm{CD} 4^{+}\right)$and $\mathrm{CD}^{+}\left(\mathrm{CD}^{+} 9^{+} \mathrm{CD} 8^{+}\right) \mathrm{T}$ cells (Figure 2A, 2B, and Figure S7). We also noted that cytotoxic $\mathrm{CD}^{+} \mathrm{T}$ cells $\left(\mathrm{CD} 107 \mathrm{a}^{+}\right.$and Granzyme $\left.\mathrm{B}^{+}\right)$, which play a crucial role in eliminating infected cells, have increased significantly after vaccination (Figure 2C and 2D). Furthermore, in the spleen of $\mathrm{S}_{\text {Omicron-6P immunized }}$ 
141 mice, we observed extensive expansion of the effector memory $\mathrm{CD} 4^{+}$and $\mathrm{CD} 8^{+} \mathrm{T}$ cells

$142\left(\mathrm{CD} 44^{+} \mathrm{CD} 62 \mathrm{~L}^{-}\right)$, which mediate protective memory (Figure $2 \mathrm{E}$ and $\left.2 \mathrm{~F}\right)$.

144 T-cell responses (Laczko et al., 2020; Vogel et al., 2021). To investigate whether our

145 SOmicron-6P activates an immune response similarly, we collected splenocytes from the

146 immunized mice and re-stimulated them with the full-length $\mathrm{S}$ peptide mix. Using an

147 enzyme-linked immunosorbent spot (ELISPOT) assay, we detected high levels of IFN-

$148 \gamma$ and interleukin-2 (IL-2) secreting Th1 cells in Somicron-6P immunized mice (Figure

$1492 \mathrm{G}$ and $2 \mathrm{H}$ ). Nevertheless, no significant difference in T-helper-2 (Th2) cytokines

150 interleukin-4 (IL-4) secretion was observed between the vaccinated and control mice

151 (Figure 2I). Intracellular-cytokine-staining flow cytometry had consistent results

152 (Figure S8). These data confirmed that Somicron-6P induces a Th1-biased immune

153 response. 

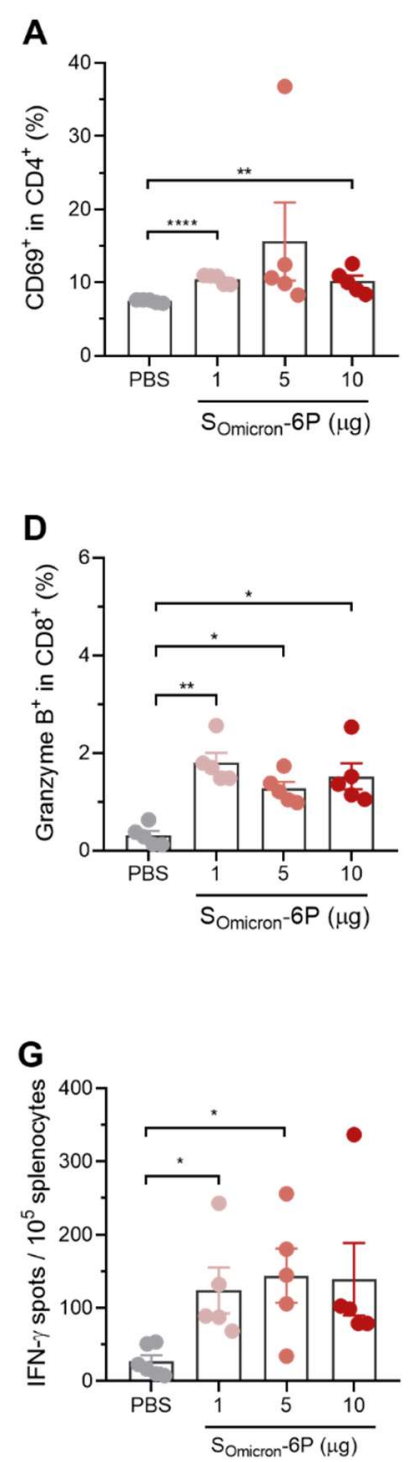

155

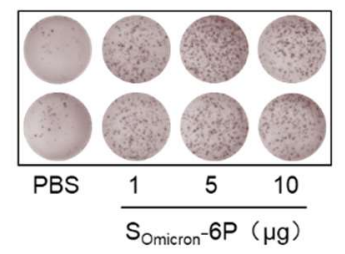

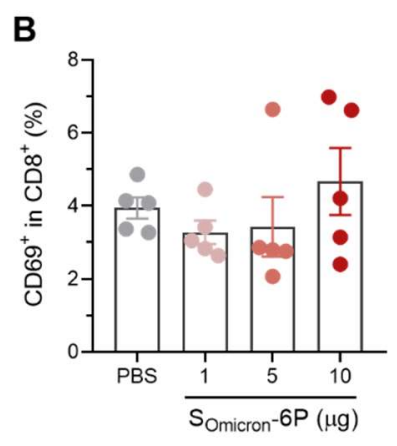

E

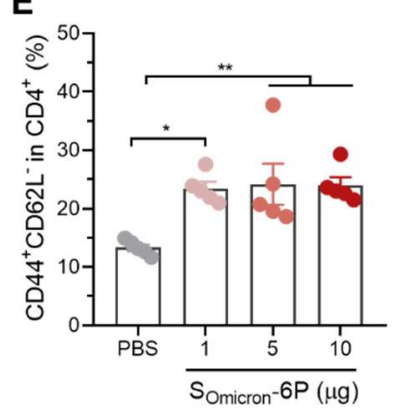

H
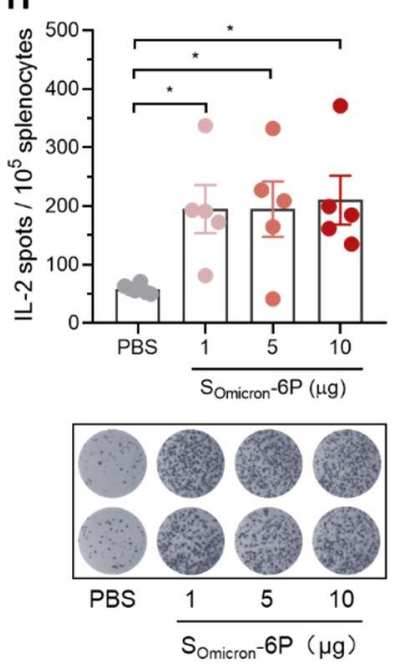

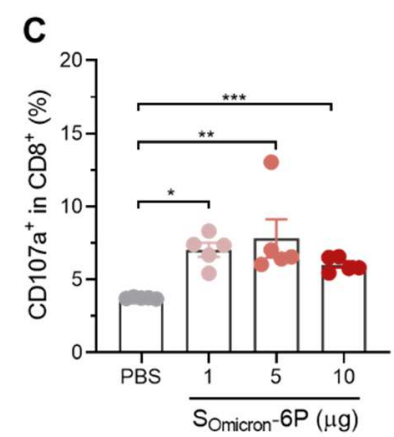

$\mathbf{F}$
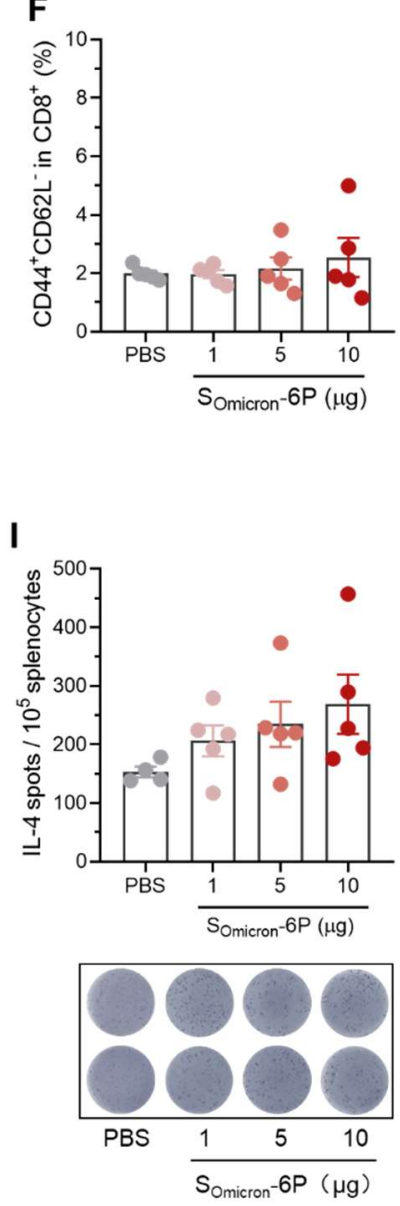

Figure 2. Somicron-6P Induces Antigen-Specific Celluar Immune Responses in Mice.

158 Female BALB/c mice were immunized with $0,1,5$ or $10 \mu \mathrm{g} \mathrm{S}_{\text {Omicron-6P. Twenty-nine }}$

159 days after the first immunization, mice were euthanized and their spleens were collected 160 for T cell response and phenotyping analysis.

161 (A-B) The percentages of activated $\left(\mathrm{CD} 69^{+}\right)(\mathrm{A}) \mathrm{CD}^{+}$and (B) $\mathrm{CD} 8^{+}$among $\mathrm{CD} 4^{+}$and $162 \mathrm{CD}^{+} \mathrm{T}$ cells.

163 (C-D) The percentages of cytotoxic $\left(\mathrm{CD} 107 \mathrm{a}^{+}\right.$and Granzyme $\left.\mathrm{B}^{+}\right) \mathrm{T}$ cells among $\mathrm{CD} 8^{+}$ 
164 T cells.

165 (E-F) The percentages of effector memory $\left(\mathrm{CD} 44^{+} \mathrm{CD} 62 \mathrm{~L}^{-}\right)$cells among $(\mathrm{E}) \mathrm{CD} 4^{+}$and

166 (F) $\mathrm{CD}^{+} \mathrm{T}$ cells.

167 (G-I) ELISPOT assay for (G) IFN- $\gamma$, (H) IL-2, and (I) IL-4 in splenocytes. Splenocytes were harvested and re-stimulated with SARS-CoV-2 S protein peptide mix for $24 \mathrm{~h}$ on day 29 after first immunization.

Data are shown as mean \pm SEM. Significance was calculated using one-way ANOVA with multiple comparisons tests $(* \mathrm{p}<0.05, * * \mathrm{p}<0.01, * * * \mathrm{p}<0.001, * * * * \mathrm{p}<0.0001)$ on day 0 and day 21 with either $1,10,25$, and $50 \mu \mathrm{g}$ of $\mathrm{S}_{\text {Omicron-6P }}$ or PBS. The hamster sera were collected and evaluated for vaccine immunogenicity on day 14, 21 and 28 (Figure 3A). A significant amount of $\operatorname{IgG}$ against $\mathrm{S}$ protein was detected on day 14 and

However, the second dose boosts $\mathrm{S}$ antibodies more than ten times one week later (on day 28) (Figure 3B and S9). The pseudovirus assay showed that high neutralizing

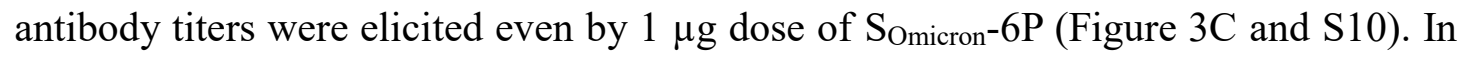
line with this, high levels of neutralizing activity against authentic Omicron in Somicron$6 \mathrm{P}$ vaccinated animals (Figure 3D). Moreover, we observed a strong correlation of co-efficiency of 0.91 (Figure 3E). 
bioRxiv preprint doi: https://doi.org/10.1101/2022.03 01.481391· this version posted March 1 2022. The copyright holder for this preprint (which was not certified by peer review) is the author/funder, who has granted bioRxiv a license to display the preprint in perpetuity. It is made available under aCC-BY-NC-ND 4.0 International license.

188

shown in Figure 3F, only a trace amount of viral RNA was detected in the lung tissue of vaccinated animals with a little more for the $1 \mu \mathrm{g}$ group, which is a 4-5 magnitude reduction than the control group. Infectious virus in lung tissue was determined with plaque assay, resulting in no detectable virus in both lungs and nasal turbinates of all vaccinated animals, including the lowest dose group, but while markedly levels of virus in the PBS group (Figure 3G). These data demonstrate that Somicron-6P provides robust protection against the infection of Omicron.

A
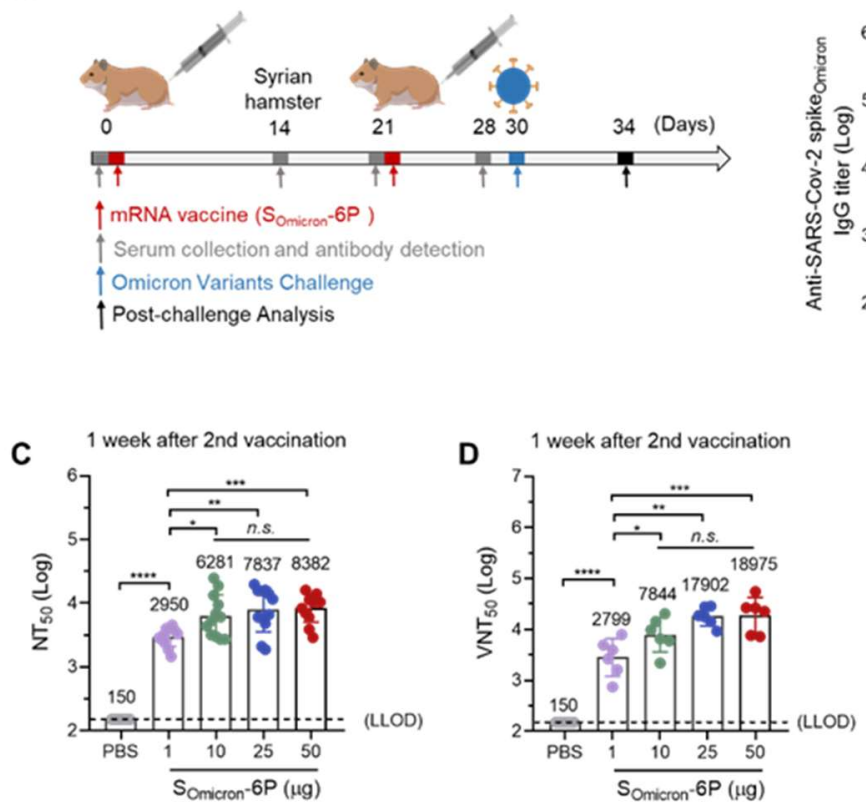

$\mathbf{F}$

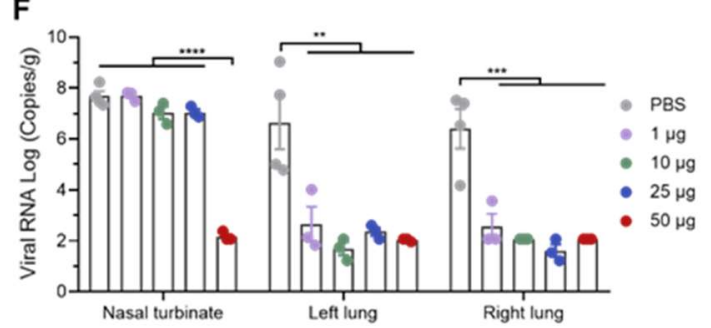

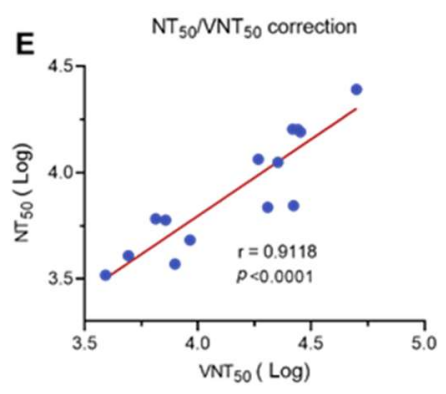

B

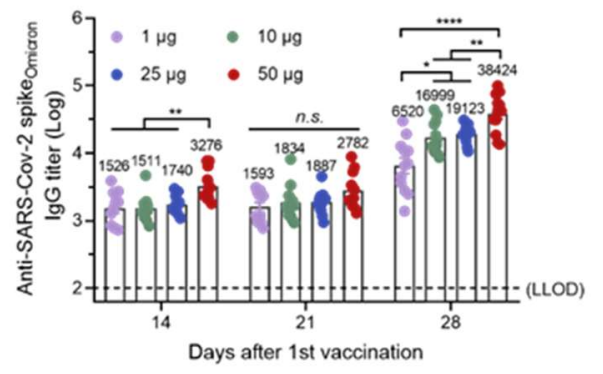

G

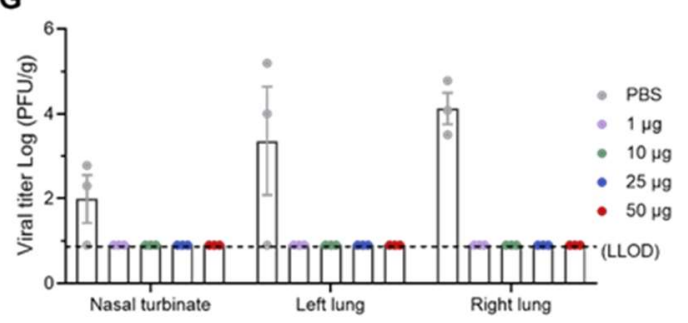

200 (A) Schematic diagram of immunization and sample collection schedule in Syrian 
201 hamsters. Female hamsters were prime-vaccinated via the i.m. route on day 0 and 202 boosted on day 21 , with $0,1,10,25$, or $50 \mu \mathrm{g}$ of Somicron-6P. On day 30 after the initial 203 immunization, hamsters were intranasally (i.n.) challenged with $1 \times 10^{4}$ PFU of SARSCoV-2 Omicron. On day 4 after infection, hamsters were euthanized for tissue collection.

(B) The Omicron SARS-CoV-2 variant specific IgG antibody titers were determined by ELISA (lower limit of detection $($ LLOD $)=100)$.

(C) $\mathrm{NT}_{50}$ values were determined by VSV-based pseudovirus (Omicron variant) neutralization assay $(\mathrm{LLOD}=150)$.

(D) $\mathrm{VNT}_{50}$ values were determined by a plaque reduction neutralization test (LLOD = $150)$.

(E) Pearson correlation of VSV-SARS-CoV-2 (Omicron variant) VNT $_{50}$ with live SARS-CoV-2 (Omicron variant) $\mathrm{VNT}_{50}$ for $\mathrm{n}=14$ random selected serum samples from mice immunized with SOmicron-6P.

(F) Viral RNA load in the both lungs and nasal turbinates were determined by qRT-PCR.

(G) Viral load expressed in PFU per gram of tissue in the both lungs and nasal turbinates at 4 dpi.

Data are shown as mean \pm SEM. Significance was calculated using one-way ANOVA with multiple comparisons tests (n.s., not significant, ${ }^{*} \mathrm{p}<0.05,{ }^{*} \mathrm{p}<0.01,{ }^{* * *} \mathrm{p}<$ $0.001, * * * * \mathrm{p}<0.0001)$.

Macaques were immunized with either 20 or $100 \mu \mathrm{g}$ of SOmicron-6P twice at a 21-day 
bioRxiv preprint doi: https://doi.org/10.1101/2022.03 01.481391· this version posted March 1, 2022. The copyright holder for this preprint (which was not certified by peer review) is the author/funder, who has granted bioRxiv a license to display the preprint in perpetuity. It is made available under aCC-BY-NC-ND 4.0 International license.

A
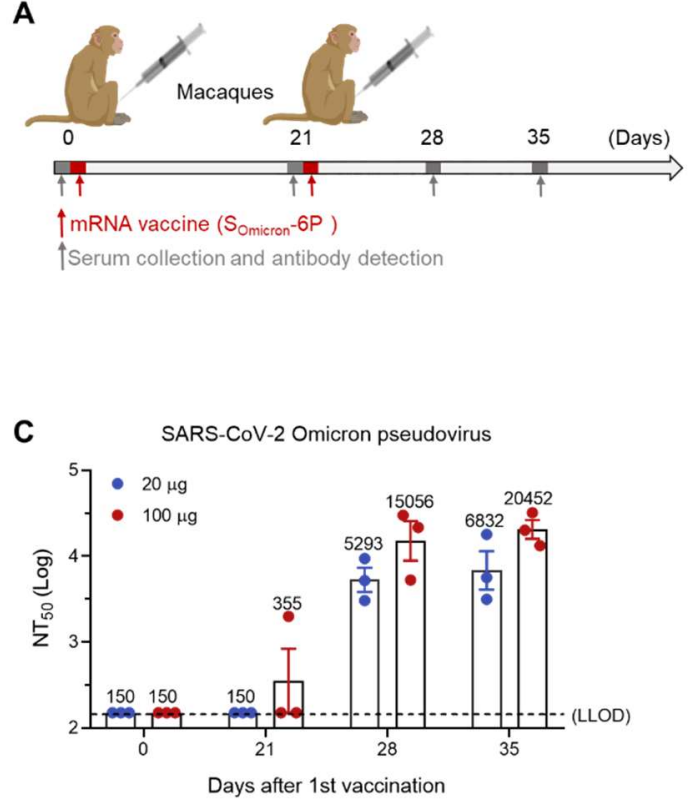

E
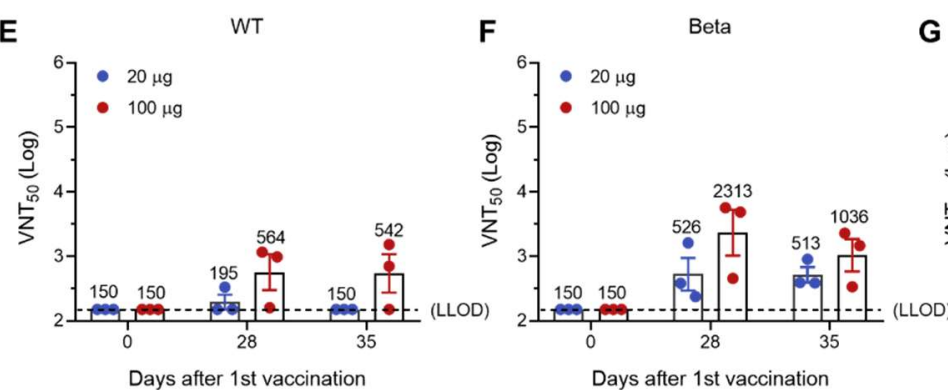

G

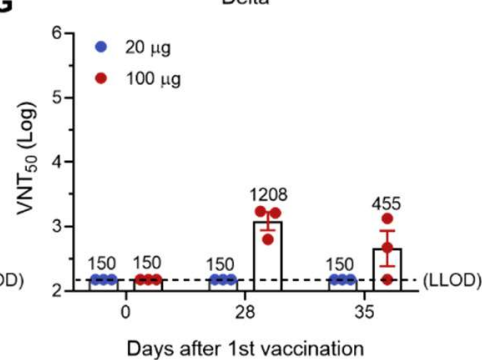


240 and boosted with the same dose at 21-day interval.

241 (B) The Omicron SARS-CoV-2 variant specific IgG antibody titers were determined by

242 ELISA (lower limit of detection $($ LLOD $)=100)$.

243 (C) $\mathrm{NT}_{50}$ values were determined by VSV-based pseudovirus (Omicron variant) 244 neutralization assay $(\mathrm{LLOD}=150)$.

245 (D-G) VNT 50 against (D) SARS-CoV-2 Omicron, (E) WT, (F) Beta, and (G) Delta that 246 were determined by a plaque reduction neutralization test $($ LLOD $=150)$.

247 Data are shown as mean \pm SEM. Significance was calculated using one-way ANOVA 248 with multiple comparisons tests. 


\section{DISCUSSION}

251 Although the fast-spreading Omicron variant seems to cause less severe symptoms, the death toll keeps rising due to Omicron's high transmissible ability (Garcia-Beltran et al., 2022). The original forms of mRNA vaccines, which have achieved remarkable clinical efficacy in protecting against prior variants of SARS-CoV-2, fail to provide as strong protection against Omicron as before. For example, the mRNA vaccine,

BNT162b2, has over 90\% efficacy against the WA1 strain; however, the efficacy dropped to around 30-50\% for Omicron (Dejnirattisai et al., 2022b). The neutralizing antibody titers evoked by BNT162b2 dropped by 15-20 folds. Therefore, the fast evolution of the virus compelled us to develop Omicron-specific mRNA vaccines.

To generate an Omicron-specific mRNA vaccine, we introduced all the mutations within the $\mathrm{S}$ protein in the mRNA sequence and designed the sequence to express prefusion S protein via six consecutive proline substitutions $\left(\mathrm{S}_{\text {Omicron-6P). }} \mathrm{S}_{\text {Omicron-6P }}\right.$ induced a 14.4 27.7-fold and a 28.3 50.3-fold increase of neutralizing activity against the pseudovirus of Omicron and authentic Omicron compared to $\mathrm{S}_{\mathrm{WT}}-2 \mathrm{P}$, respectively. Assuming that neutralizing antibody titers positively correlate to the protection efficacy, we anticipate that our Omicron-specific mRNA vaccine would restore its clinical effectiveness to at least $90 \%$. Both the $6 \mathrm{P}$ design and the inclusion of all Omicronspecific mutations may contribute to the strong immunity evoked by the Omicronspecific mRNA vaccine. induces multicomponent immune responses, including memory $\mathrm{B}$ and $\mathrm{T}$ cell responses, 
272

273

a Th1-biased T cell immunity, and a cytotoxic $\mathrm{T}$ cell response. The induction of immune response is similar to the prior version of mRNA vaccines, suggesting that changes in mRNA sequence do not alter the generic mechanisms of how mRNA-LNP-based vaccines activate cellular immunity.

In this study, we have conducted a comprehensive analysis of the effects of the Omicron-specific mRNA vaccine using several animal models, including mice, Syrian hamsters, and macaques. All the tested animals developed strong immune responses and were well protected from developing disease against Omicron virus challenge in hamsters. We noticed that in Syrian hamster model, only the highest dose of vaccines shows effective reduction of RNA copies in the nasal turbinate where SARS-COV2 replicates the most on day 4. In addition, no live Omicron virus was detected in nasal turbinates of all the Somicron-6P-vaccinated hamsters. Note that we infected the animals by directly adding the Omicron viruses into the nasal cavity, and it may take a more extended period for the viral RNAs to degrade.

Most importantly, our data strongly suggest that two doses of Omicron-specific mRNA vaccine provide enhanced protection against Omicron compared with two doses of the prior version of mRNA vaccines with a booster. We note that several preprint studies published on bioRxiv indicate that the Omicron-specific booster offered no better protection against the Omicron variant than the $\mathrm{S}_{\mathrm{WT}}-2 \mathrm{P}$ booster (Ying et al., 2022). Note that the experimental settings of our study are different from these studies. We compare the immune protection effect against Omicron between Omicron-specific mRNA vaccines and wild type mRNA vaccines on naïve animals that have not been 

Omicron-specific mRNA vaccines elicit enhanced protection for naïve animals. We think that highly the mutated S protein of Omicron has significantly compromised the

297 immune memories induced by the prior version of vaccines so that a single dose of a

298 booster, no matter Omicron-specific or not, is not potent enough to elicit immune 299 protection effectively. Based on the results from our study, we urge that those with 300 weaker immune systems should get at least two doses of Omicron-specific mRNA 301 vaccines instead of getting a booster in addition to two doses of vaccines against prior 302 SARS-CoV-2 variants. Furthermore, our data also suggest that Omicron-specific vaccines show considerable cross-protection against Beta variants, but lower protection 304 against wild type and Delta variant. This also urges the necessity for development of multi-valent vaccine to fight against the evolution of SARS-CoV-2. 


\section{ACKNOWLEDGMENTS}

308 This work was supported by the National Key R\&D Program of China

309 (2020YFA0710700), the National Natural Science Foundation of China (52025036,

310 51961145109), the Fundamental Research Fund for the Central Universities

311 (WK9100000014, WK2480000006), and the project of collaborative innovation for colleges of Anhui province (NO. GXXT-2021-070). This work was partially carried out

313 at the USTC Center for Micro and Nanoscale Research and Fabrication. We thank Jia

314 Wu, Jun Liu and Hao Tang from Wuhan Institute of Virology for managing of BSL-3

315 facility, where all the authentic SARS-CoV-2 experiments were conducted. We also thank National Virus Resource Center for providing the Omicron variant (CCPM-B-V-

317 049-2112-18). We thank Weiheng Chen from the Animal Facility of USTC, where the

318 mice, hamsters, and macaques were vaccinated. We thank the Joint Laboratory of

319 Innovation in Life Sciences University of Science and Technology of China (USTC) 320 and Changchun Zhuoyi Biological Co. Ltd. 


\section{AUTHOR CONTRIBUTIONS}

323

C. W., N.-N.X., Y.-C.W., and S.C. supervised the project. Yi W., Y.-Q.S., N.-M.W., Y.-

C.W., and S.C. conceived the experiments. Yi W., Y.-Q.S., N.-M.W., X.-H.Z., S.-H.C.,

C.Y., H.-J.Z., Yan W., D.C., L.W., Y.-Y.W., J.-J.X., K.L. conducted the experiments and analyzed the data. Yi W., Y.-Q.S., N.-M.W., N.-N.X., and Y.-C.W. wrote and revised the manuscript. C. W., H.-J.Z., and S.C. revised the manuscript. Y.-Y.W., J.-J.X., and K.L. are employees of Hefei RNAlfa Biotech. All authors read and approved the manuscript. 
bioRxiv preprint doi: https://doi.org/10.1101/2022.03.01.481391; this version posted March 1, 2022. The copyright holder for this preprint (which was not certified by peer review) is the author/funder, who has granted bioRxiv a license to display the preprint in perpetuity. It is made available under aCC-BY-NC-ND 4.0 International license.

\section{DECLARATION OF INTERESTS}

331 N.-N.X., Y.-C.W. are co-inventors on pending patent applications related to the

332 Omicron mRNA vaccine. The other authors declare no known competing financial

333 interests or personal relationships that could have appeared to influence the work

334 reported in this paper.

335 
Cao, Y., Wang, J., Jian, F., Xiao, T., Song, W., Yisimayi, A., Huang, W., Li, Q., Wang, P., An, R., et al. (2021). Omicron escapes the majority of existing SARS-CoV-2 neutralizing antibodies. Nature 602, 657-663.

Cele, S., Jackson, L., Khoury, D.S., Khan, K., Moyo-Gwete, T., Tegally, H., San, J.E., Cromer, D., Scheepers, C., Amoako, D.G., et al. (2021). Omicron extensively but incompletely escapes Pfizer BNT162b2 neutralization. Nature 602, 654-656

Dejnirattisai, W., Huo, J., Zhou, D., Zahradnik, J., Supasa, P., Liu, C., Duyvesteyn, H.M.E., Ginn, H.M., Mentzer, A.J., Tuekprakhon, A., et al. (2022a). SARS-CoV-2 Omicron-B.1.1.529 leads to widespread escape from neutralizing antibody responses. Cell 185, 467-484 e415.

Dejnirattisai, W., Shaw, R.H., Supasa, P., Liu, C., Stuart, A.S.V., Pollard, A.J., Liu, X.X., Lambe, T., Crook, D., Stuart, D.I., et al. (2022b). Reduced neutralisation of SARSCoV-2 omicron B.1.1.529 variant by post-immunisation serum. Lancet 399, 234-236.

Feng, L., Wang, Q., Shan, C., Yang, C., Feng, Y., Wu, J., Liu, X., Zhou, Y., Jiang, R., $\mathrm{Hu}$, P., et al. (2020). An adenovirus-vectored COVID-19 vaccine confers protection from SARS-COV-2 challenge in rhesus macaques. Nat. Commun. 11, 4207.

Flemming, A. (2022). Omicron, the great escape artist. Nat. Rev. Immunol. 22, 75.

Garcia-Beltran, W.F., St Denis, K.J., Hoelzemer, A., Lam, E.C., Nitido, A.D., Sheehan, M.L., Berrios, C., Ofoman, O., Chang, C.C., Hauser, B.M., et al. (2022). mRNA-based COVID-19 vaccine boosters induce neutralizing immunity against SARS-CoV-2 Omicron variant. Cell 185, 457-466 e454.

Hsieh, C.L., Goldsmith, J.A., Schaub, J.M., DiVenere, A.M., Kuo, H.C., Javanmardi, K., Le, K.C., Wrapp, D., Lee, A.G., Liu, Y., et al. (2020). Structure-based design of prefusion-stabilized SARS-CoV-2 spikes. Science 369, 1501-1505.

Hu, J., Peng, P., Cao, X., Wu, K., Chen, J., Wang, K., Tang, N., and Huang, A.L. (2022). Increased immune escape of the new SARS-CoV-2 variant of concern Omicron. Cell. Mol. Immunol. 19, 293-295.

Karim, S.S.A., and Karim, Q.A. (2021). Omicron SARS-CoV-2 variant: a new chapter in the COVID-19 pandemic. Lancet 398, 2126-2128.

Koh, H.K., Geller, A.C., and VanderWeele, T.J. (2021). Deaths from COVID-19. JAMA 325, 133-134.

Laczko, D., Hogan, M.J., Toulmin, S.A., Hicks, P., Lederer, K., Gaudette, B.T., Castano, D., Amanat, F., Muramatsu, H., Oguin, T.H., 3rd, et al. (2020). A single immunization with nucleoside-modified mRNA vaccines elicits strong cellular and humoral immune responses against SARS-CoV-2 in mice. Immunity 53, 724-732 e727.

Liu, J., Chandrashekar, A., Sellers, D., Barrett, J., Jacob-Dolan, C., Lifton, M., 
McMahan, K., Sciacca, M., VanWyk, H., Wu, C., et al. (2022). Vaccines elicit highly conserved cellular immunity to SARS-CoV-2 Omicron. Nature. Published online January 31, 2022. https://doi. org/10.1038/s41586-022-04465-y.

Maier, M.A., Jayaraman, M., Matsuda, S., Liu, J., Barros, S., Querbes, W., Tam, Y.K., Ansell, S.M., Kumar, V., Qin, J., et al. (2013). Biodegradable lipids enabling rapidly eliminated lipid nanoparticles for systemic delivery of RNAi therapeutics. Mol. Ther. $21,1570-1578$.

Malik, J.A., Ahmed, S., Mir, A., Shinde, M., Bender, O., Alshammari, F., Ansari, M., and Anwar, S. (2022). The SARS-CoV-2 mutations versus vaccine effectiveness: New opportunities to new challenges. J. Infect. Public Health 15, 228-240.

Mistry, P., Barmania, F., Mellet, J., Peta, K., Strydom, A., Viljoen, I.M., James, W., Gordon, S., and Pepper, M.S. (2021). SARS-CoV-2 variants, vaccines, and host immunity. Front Immunol. 12, 809244.

Munoz-Fontela, C., Dowling, W.E., Funnell, S.G.P., Gsell, P.S., Riveros-Balta, A.X., Albrecht, R.A., Andersen, H., Baric, R.S., Carroll, M.W., Cavaleri, M., et al. (2020). Animal models for COVID-19. Nature 586, 509-515.

Pia, L., and Rowland-Jones, S. (2022). Omicron entry route. Nat. Rev. Immunol. Published online January 26, 2022. https://doi. org/10.1038/s41577-022-00681-9.

Planas, D., Saunders, N., Maes, P., Guivel-Benhassine, F., Planchais, C., Buchrieser, J., Bolland, W.H., Porrot, F., Staropoli, I., Lemoine, F., et al. (2021). Considerable escape of SARS-CoV-2 Omicron to antibody neutralization. Nature 602, 671-675.

Sun, C., Kang, Y.F., Liu, Y.T., Kong, X.W., Xu, H.Q., Xiong, D., Xie, C., Liu, Y.H., Peng, S., Feng, G.K., et al. (2022). Parallel profiling of antigenicity alteration and immune escape of SARS-CoV-2 Omicron and other variants. Signal Transduct. Target. Ther. 7,42 .

Suzuki, R., Yamasoba, D., Kimura, I., Wang, L., Kishimoto, M., Ito, J., Morioka, Y., Nao, N., Nasser, H., Uriu, K., et al. (2022). Attenuated fusogenicity and pathogenicity of SARS-CoV-2 Omicron variant. Nature. Published online February 1, 2022. https://doi. org/10.1038/s41586-022-04462-1.

Thompson, M.G., Stenehjem, E., Grannis, S., Ball, S.W., Naleway, A.L., Ong, T.C., DeSilva, M.B., Natarajan, K., Bozio, C.H., Lewis, N., et al. (2021). Effectiveness of Covid-19 vaccines in ambulatory and inpatient care settings. N. Engl. J. Med. 385, 1355-1371.

VanBlargan, L.A., Errico, J.M., Halfmann, P.J., Zost, S.J., Crowe, J.E., Jr., Purcell, L.A., Kawaoka, Y., Corti, D., Fremont, D.H., and Diamond, M.S. (2022). An infectious SARS-CoV-2 B.1.1.529 Omicron virus escapes neutralization by therapeutic monoclonal antibodies. Nat. Med. Published online January 19, 2022. https://doi. org/10.1038/s41591-021-01678-y.

Vogel, A.B., Kanevsky, I., Che, Y., Swanson, K.A., Muik, A., Vormehr, M., Kranz, L.M., 
412 Walzer, K.C., Hein, S., Guler, A., et al. (2021). BNT162b vaccines protect rhesus

413 macaques from SARS-CoV-2. Nature 592, 283-289.

414 Wang, Z.J., Zhang, H.J., Lu, J., Xu, K.W., Peng, C., Guo, J., Gao, X.X., Wan, X., Wang, 415 W.H., Shan, C., et al. (2020). Low toxicity and high immunogenicity of an inactivated 416 vaccine candidate against COVID-19 in different animal models. Emerg. Microbes 417 Infect. 9, 2606-2618.

418 Ying, B., Scheaffer, S.M., Whitener, B., Liang, C.Y., Dmytrenko, O., Mackin, S., Wu, 419 K., Lee, D., Avena, L.E., Chong, Z., et al. (2022). Boosting with Omicron-matched or 420 historical mRNA vaccines increases neutralizing antibody responses and protection 421 against B.1.1.529 infection in mice. bioRxiv. https://doi. $422 \quad$ org/10.1101/2022.02.07.479419.

423 Zhang, Q., Zhang, H., Gao, J., Huang, K., Yang, Y., Hui, X., He, X., Li, C., Gong, W., 424 Zhang, Y., et al. (2020). A serological survey of SARS-CoV-2 in cat in Wuhan. Emerg. 425 Microbes Infect. 9, 2013-2019. 
bioRxiv preprint doi: https://doi org/101101/2022 03.01.481391; this version posted March 1, 2022. The copyright holder for this preprint (which was not certified by peer review) is the author/funder, who has granted bioRxiv a license to display the preprint in perpetuity. It is made available under aCC-BY-NC-ND 4.0 International license.

\begin{tabular}{|c|c|c|}
\hline REGENT or RESOURCE & SOURCE & IDENTIFIER \\
\hline \multicolumn{3}{|l|}{ Antibodies } \\
\hline $\begin{array}{l}\text { APC/Cyanine } 7 \text { anti-mouse CD } 45 \\
\text { Antibody }\end{array}$ & Biolegend & Ca\#\#103116; RRID: AB_312981 \\
\hline $\begin{array}{l}\text { PE/Cyanine } 7 \text { anti-mouse CD4 } \\
\text { Antibody }\end{array}$ & Biolegend & Cat\#100528; RRID: AB_312729 \\
\hline $\begin{array}{l}\text { PerCP/Cyanine } 5.5 \text { anti-mouse } \\
\text { CD8a Antibody }\end{array}$ & Biolegend & Cat\#100734; RRID: AB_2075238 \\
\hline PE anti-mouse IL-4 Antibody & Biolegend & Cat\#504104; RRID: AB_315318 \\
\hline APC anti-mouse IL-2 Antibody & Biolegend & Cat\#503810; RRID: AB_315304 \\
\hline 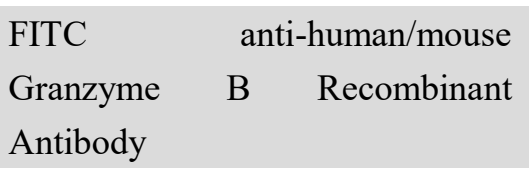 & Biolegend & Cat\#372206; RRID: AB_2687030 \\
\hline PE anti-mouse IFN- $\gamma$ Antibody & Biolegend & Cat\#505808; RRID: AB_315402 \\
\hline APC anti-mouse TNF- $\alpha$ Antibody & Biolegend & Cat\#506308; RRID: AB_315429 \\
\hline APC anti-mouse CD4 Antibody & Biolegend & Cat\#100516: RRID: AB_312719 \\
\hline PE anti-mouse CD8a Antibody & Biolegend & Cat\#100708; RRID: AB_312747 \\
\hline $\begin{array}{l}\text { PerCP/Cyanine5.5 anti- } \\
\text { mouse/human CD44 Antibody }\end{array}$ & Biolegend & Cat\#103032; RRID: AB_2076204 \\
\hline $\begin{array}{l}\text { Brilliant Violet } 510^{\mathrm{TM}} \text { anti-mouse } \\
\text { CD62L Antibody }\end{array}$ & Biolegend & Cat\#104441; RRID: AB_2561537 \\
\hline $\begin{array}{l}\text { FITC anti-mouse } \quad \text { CD107a } \\
\text { (LAMP-1) Antibody }\end{array}$ & Biolegend & Cat\#121606; RRID: AB_572007 \\
\hline $\begin{array}{l}\text { PE/Cyanine7 anti-mouse CD69 } \\
\text { Antibody }\end{array}$ & Biolegend & Cat\#104512; RRID: AB_493564 \\
\hline $\begin{array}{l}\text { FITC anti-mouse } \quad \text { CD45.2 } \\
\text { Antibody }\end{array}$ & Biolegend & Cat\#109806; RRID: AB_313443 \\
\hline $\begin{array}{l}\text { APC/Cyanine } 7 \text { anti-mouse CD19 } \\
\text { Antibody }\end{array}$ & Biolegend & Cat\#115530; RRID: AB_830707 \\
\hline $\begin{array}{ll}\text { APC anti-mouse } & \text { CD138 } \\
\text { (Syndecan-1) Antibody } & \end{array}$ & Biolegend & Cat\#142506; RRID: AB_10962911 \\
\hline $\begin{array}{l}\text { APC anti-mouse CD185 (CXCR5) } \\
\text { Antibody }\end{array}$ & Biolegend & Cat\#145506; RRID: AB_2561970 \\
\hline $\begin{array}{l}\mathrm{PE} \text { anti-mouse/human } \\
\text { CD45R/B220 Antibody }\end{array}$ & Biolegend & Cat\#103208; RRID: AB_312993 \\
\hline $\begin{array}{l}\text { HRP-conjugated Goat anti-Mouse } \\
\text { IgG }\end{array}$ & Sangon Biotech & Cat\#D110087 \\
\hline Goat anti-Monkey $\operatorname{IgG}(\mathrm{H} \& \mathrm{~L})$ & Thermo Fisher & Cat\#PA1-84631; RRID: AB_933605 \\
\hline
\end{tabular}




\begin{tabular}{|c|c|c|}
\hline \multicolumn{3}{|l|}{ Secondary Antibody, HRP } \\
\hline $\begin{array}{l}\text { Goat anti-Syrian Hamster IgG } \\
\text { H\&L (HRP) }\end{array}$ & Abcam & Cat\#ab6892; RRID: AB_955427 \\
\hline $\begin{array}{l}\text { SARS-CoV-2 (2019-nCoV) Spike } \\
\text { Neutralizing Antibody }\end{array}$ & Sino Biological & Cat\#40592-R0004 \\
\hline $\begin{array}{l}\text { Purified Rat anti-Mouse } \\
\text { CD16/CD32 }\end{array}$ & BD Biosciences & Cat\# 553142; RRID: AB_394657 \\
\hline Goat anti-Rabbit IgG (FITC) & Abcam & Cat\#ab6717; RRID: AB_955238 \\
\hline \multicolumn{3}{|l|}{ Virus Strains } \\
\hline $\begin{array}{l}\text { SARS-CoV-2-Fluc } \\
\text { pseudovirus }\end{array}$ & Vazyme Biotech & Cat\#DD1568-03 \\
\hline SARS-CoV-2 WIV04 strain & N/A & N/A \\
\hline SARS-CoV-2 Beta variant & N/A & N/A \\
\hline SARS-CoV-2 Delta variant & N/A & N/A \\
\hline SARS-CoV-2 Omicron variant & N/A & N/A \\
\hline \multicolumn{3}{|c|}{ Chemicals, Peptides, and Recombinant Proteins } \\
\hline $\begin{array}{l}\text { SARS-CoV-2 } \\
\text { (Omicron) } \mathrm{S} 1+\mathrm{S} 2 \text { trimer Protein }\end{array}$ & Sino Biological & Cat\#40589-V08H26 \\
\hline SARS-CoV-2 Spike Peptide Pool & Sino Biological & Cat\#PP003 \\
\hline $\begin{array}{l}\text { eBioscience }^{\mathrm{TM}} \text { Cell Stimulation } \\
\text { Cocktail }(500 \times)\end{array}$ & Invitrogen & $\mathrm{Ca} \# 00-4970$ \\
\hline $\begin{array}{l}\text { Foxp3/Transcription } \quad \text { Factor } \\
\text { Staining Buffer Set }\end{array}$ & Invitrogen & $\mathrm{Cat} \# 00-5523-00$ \\
\hline $\begin{array}{l}\text { Lipofectamine }{ }^{\circledR} \\
\text { MessengerMAX } \\
\end{array}$ & Invitrogen & Cat\#LMRNA008 \\
\hline Penicillin Streptomycin & Gibco & Cat\#15140 \\
\hline Fetal Bovine Serum & ExCell Bio & Cat\#FSP500 \\
\hline $\begin{array}{l}\text { Dulbecco's modified eagle } \\
\text { medium (DMEM) }\end{array}$ & Gibco & Cat\#C11995500BT \\
\hline RPMI Medium 1640 & Gibco & Cat\#C11875500BT \\
\hline DAPI & Sigma-Aldrich & Cat\#28718-90-3 \\
\hline Non-Fat Powdered Milk & Sangon Biotech & Cat\#A600669-0250 \\
\hline Bio-Lite Luciferase Assay System & Vazyme Biotech & Cat\#DD1201-01/02/03 \\
\hline $\begin{array}{l}\text { eBioscience }^{\mathrm{TM}} \text { Protein Transport } \\
\text { Inhibitor Cocktail }(500 \times)\end{array}$ & Invitrogen & Cat $\# 00-4980$ \\
\hline ACK Lysis Buffer & Beyotime & Cat\#3702 \\
\hline TMB Substrate Solution & Beyotime & Cat\#P0209 \\
\hline Stop Solution for TMB Substrate & Beyotime & Cat\#P0215 \\
\hline Critical Commercial Assays & & \\
\hline Mouse IL-4 ELISPOT ${ }^{\text {PLUS }}$ Kit & MabTech & Cat\#3311-4HPW \\
\hline Mouse IL-2 ELISPOT ${ }^{\text {PLUS }}$ Kit & MabTech & Cat\#3441-4HPW \\
\hline
\end{tabular}




\begin{tabular}{lll}
$\begin{array}{l}\text { Mouse IFN- } \gamma \text { Precoated ELISPOT } \\
\text { Kit }\end{array}$ & Dakewe Biotech & Cat\#2210005 \\
\hline Cell Lines & $\begin{array}{l}\text { Provided by N/A } \\
\text { Vazyme Biotech }\end{array}$ & \\
\hline Vero cells & ATCC & Cat\#CRL-1586 \\
\hline Vero E6 cells & ATCC & Cat\#CRL11268 \\
\hline HEK293T cells & & \\
\hline Animals & Jiangsu & N/A \\
\hline BALB/c mice & GemPharmatech & \\
\hline Syrian hamster & Beijing Vital River & N/A \\
\hline Macaques & $\begin{array}{l}\text { Anhui } \\
\text { Macaque breeding }\end{array}$ & N/A \\
\hline Co. LTD & \\
\hline GraphPad prism & GraphPad & N/A \\
\hline ImageJ & software & N/A \\
\hline FlowJo software & NIH software & N/A \\
\hline
\end{tabular}

430

431

432

433

\section{EXPERIMENTAL MODEL AND SUBJECT DETAILS}

\section{Ethics statement}

All mouse and macaque studies were conducted under protocols approved by the Institutional Animal Care and Use Committee of the University of Science and Technology of China. All procedures performed on Syrian hamster were in accordance with regulations and established guidelines, and were reviewed and approved by the Animal Ethics Committee of the Wuhan Institute of Biological Products (WIBP) (WIBP-AII382020001). The animals received care in compliance with the guidelines outlined in the Guide for the Care and Use of Laboratory Animals. 
443

444

445

446

447

448

449

450

451

452

453

454

455

456

457

458

459

460

461

462

463

464

\section{Cells and viruses}

HEK293T cells, Vero cells, and Vero E6 cells were cultured in Dulbecco's modified Eagle's medium (DMEM, Gibco) supplemented with 10\% fetal bovine serum (FBS, ExCell Bio) and $1 \%$ penicillin-streptomycin (Gibco) at $37^{\circ} \mathrm{C}$ under a $5 \% \mathrm{CO}_{2}$ atmosphere. The SARS-CoV-2 WIV04 strain was initially isolated from a COVID-19 patient in 2019 (GISAID, accession no. EPI_ISL_402124); Beta variant (NPRC2.062100001) was kindly provided by Chinese Center for Disease Control and Prevention, and Delta variant (B.1.617.2; GWHBEBW01000000) by Prof. Hongping Wei; Omicron variant was isolated from a throat swab of a patient from Hong Kong by the Institute of Laboratory Animal Sciences, Chinese Academy of Medical Sciences (CCPM-B-V-049-2112-18). All processes in this study involving authentic SARS-CoV2 were performed in a BSL-3 facility.

\section{METHOD DETAILS}

\section{mRNA design and synthesis}

Spike (S) protein encoded by $\mathrm{S}_{\mathrm{WT}}-2 \mathrm{P}$ vaccine was designed from original ancestral SARS-CoV-2 WA1 (GenBank MN908947.3), SOmicron-6P was based on a background of S sequences from SARS-CoV-2 variant Omicron (B.1.1.529) (GISAID: GR/484A). The template for the $\mathrm{S}_{\mathrm{WT}}-2 \mathrm{P}$ mRNA is a DNA fragment encoding SARS-CoV-2 S with K986P and V987P substitutions. The template for the Somicron-6P mRNA is a DNA fragment encoding Omicron variant S with F817P, A892P, A899P, A942P, K986P, and V987P substitutions. Both mRNAs were synthesized in vitro using an optimized T7 
RNA polymerase-mediated transcription reaction with complete replacement of uridine by N1-methyl-pseudouridine. The reaction included a DNA template containing the open reading frame flanked by 5' untranslated region (UTR) and 3' UTR sequences and was terminated by an encoded poly A tail. tangential flow filtration into sodium acetate, and sterile filtered. RNA integrity was assessed by microfluidic capillary electrophoresis (Fragment Analyzer systems 5200, Agilent), and the concentration, $\mathrm{pH}$, residual DNA, proteins, and dsRNA impurities of the solution were determined. The mRNA 5' capping efficiency and 3'-polyadenosine (poly A) tail of mRNAs was studied using liquid chromatography coupled to mass spectrometry (LC-MS).

\section{mRNA vaccine production}

mRNAs were encapsulated in LNPs using a modified procedure of a method previously as previously described (Maier et al., 2013) wherein an ethanolic lipid mixture of ionizable cationic lipid, phosphatidylcholine, cholesterol, and polyethylene glycol-lipid was rapidly mixed with an aqueous solution containing mRNA. The drug product underwent analytical characterization, which included the determination of particle size and polydispersity, encapsulation, $\mathrm{pH}$, endotoxin, and bioburden, and the material was deemed acceptable for in vivo study. 
487

488

HEK293T were seeded in 24-well plates at $1.5 \times 10^{4}$ cells/well. After $12 \mathrm{~h}$, the cells were transfected with Somicron-6P mRNA using Lipofectamine ${ }^{\circledR}$ Messenger MAX ${ }^{\mathrm{TM}}$ Reagent (Invitrogen). And $6 \mathrm{~h}$ later, the medium was replaced with DMEM medium (Gibco).

\section{Vaccine antigen detection by immunofluorescence}

Transfected HEK293T cells were fixed in 4\% paraformaldehyde (PFA) and permeabilized in PBS/0.1\% Triton X-100. Free binding sites were blocked with $1 \%$ BSA for $0.5 \mathrm{~h}$ at room temperature. Then cells were incubated with SARS-CoV-2 S neutralizing antibody (Sino Biological, 40592-R0004) that recognizes Omicron S protein. The cells were stained with an anti-rabbit fluorescent IgG secondary antibody, and nucleus DNA was stained with DAPI (Sigma-Aldrich). Images were acquired with a laser scanning confocal microscope (Nikon A1).

\section{Mouse immunizations}

Female BALB/c mice (8-12 weeks old) were randomly allocated to groups. For $\mathrm{S}_{\mathrm{WT}}-$ 2P and SOmicron-6P mRNA groups, the mice were immunized intramuscularly with 1, 5, and $10 \mu \mathrm{g}$ of mRNA vaccine, respectively. For clinically approved inactivated vaccines, the mice were intramuscularly (i.m.) immunized with $50 \mu \mathrm{L}$ and $100 \mu \mathrm{L}$ of the vaccine (500 $\mu \mathrm{L} /$ vial for an adult), respectively. For clinically approved protein subunit vaccine, mice were i.m. immunized with 10,50 , and $100 \mu \mathrm{L}$ of the vaccine $(500 \mu \mathrm{L} /$ vial for an adult), respectively. Mice were immunized with the same dose at 21-day intervals for 
mRNA vaccines or 28-day intervals for inactivated vaccine or protein subunit vaccine.

SARS-CoV-2 Omicron variant-specific IgG and nAbs titers as described below. described below.

\section{Hamster immunization and challenge experiments}

517

527 changes.

\section{Macaque immunizations}

Male macaques (3-5 years old) were randomly assigned to receive $\mathrm{S}_{\text {Omicron-6P }}$ (20 or 
531

532

$100 \mu \mathrm{g}$ ) on day 0 (the day for the first vaccination) and 21. The vaccine was administered i.m. injection in the quadriceps muscle. Blood was collected on day 0,21 , 28, and 35 after the first immunization to detect Omicron variant S protein-specific IgG and nAbs as described below.

\section{Enzyme linked immunosorbent assay (ELISA)}

Nunc Maxisorp ELISA plates (ThermoFisher) were coated with $100 \mathrm{ng}$ per well of SARS-CoV-2 B.1.1.529 (Omicron) S1 + S2 trimer protein (Sino Biological) in PBS overnight at $4^{\circ} \mathrm{C}$. The coated plates were washed 4 times with PBS and blocked with 5\% skim milk powder in PBST (0.1\% Tween-20 in PBS) for $2 \mathrm{~h}$. After blocks, plates were incubated with serial dilutions of heat-inactivated sera in blocking buffer for $1 \mathrm{~h}$ at room temperature, followed by 4 washes. HRP-conjugated secondary antibody was diluted 1:10,000 in blocking buffer and incubated for 1 hour, followed by 4 washes. TMB (Beyotime) substrate was added and reacted under dark for 8 minutes. The absorbance was measured at $450 \mathrm{~nm}$ using a SpectraMax iD5 microplate reader.

\section{Pseudovirus neutralization assays}

A recombinant vesicular stomatitis virus (VSV)-based pseudovirus neutralization assay was used to measure neutralizing antibodies. The SARS-CoV-2-Fluc B.1.1.529 pseudovirus (Vazyme Biotech, DD1568-03) was used. In brief, pseudovirus carrying a luciferase reporter and encapsulated in Omicron variant S proteins were incubated with six 4-fold serial dilutions of the heat-inactivated serum samples by DMEM (Gibco) for 
553

554

555

556

557

558

559

560

561

562

563

564

565

566

567

568

569

570

571

572

573

574

$1 \mathrm{~h}$ at $37^{\circ} \mathrm{C}$. The mixture was then added to the Vero cells culture (Vazyme Biotech) in 96-well plates with DMEM /10\% FBS/1\% penicillin-streptomycin and incubated in a humidified cell culture chamber at $37^{\circ} \mathrm{C}$ with $5 \% \mathrm{CO}_{2}$ for 24 hours. The medium was removed at the end of incubation, and $100 \mu \mathrm{L}$ one-step luciferase detection reagent (Vazyme Biotech, DD1201-03) was added to each well. Luminescence in relative light units (RLUs) was measured by a luminometer (SpectraMax iD5, Molecular Devices) after 3 minutes of incubation at room temperature. Serum samples may be diluted to meet the initial volume requirement. RLUs of sample wells were normalized with positive control wells, and $\mathrm{NT}_{50}$ was calculated as EC50 by a normalized fourparameter sigmoid curve fit with constrains of EC50 $>0$ and hillslope $>0$ in Prism 8.0 (GraphPad).

\section{Plaque reduction neutralization assay}

The plaque reduction neutralization assay was carried out as described before (Wang et al., 2020). Sera were inactivated at $56^{\circ} \mathrm{C}$ for $30 \mathrm{~min}$ before use. The sera were diluted 150-fold first, and then 3-fold serial dilutions were prepared in the maintenance medium. The virus suspension $(0.25 \mathrm{~mL}, 600 \mathrm{PFU} / \mathrm{mL})$ was mixed with an equal volume of antiserum at desirable dilution and incubated for $1 \mathrm{~h}$. The mixture was added to monolayer cells in 24-well plates and incubated for $1 \mathrm{~h}$. After removing of the mixture, $2 \mathrm{~mL}$ of maintenance medium containing $0.9 \%$ of methylcellulose were added to each well. The plates were incubated in a $5 \% \mathrm{CO}_{2}$-air incubator at $37^{\circ} \mathrm{C}$ for $3-4$ days. The neutralizing titer was calculated as reciprocal of the highest sera dilution suppressing 
575

576

577

$50 \%$ of plaque forming. Plaque reduction $\mathrm{nAb}$ titer $\left(\mathrm{VNT}_{50}, 95 \% \mathrm{CI}\right.$, challenge viruses used: 30-300 PFU/well) was calculated as the "inhibitor vs normalized response (Variable slope)" model in the GraphPad Prism 8.0 software.

\section{Flow cytometry}

Sample processing: spleens were collected in PBS and homogenized through a $70 \mu \mathrm{m}$ cell strainer using the stern end of a syringe plunger. Splenocytes were incubated in ACK lysis buffer to remove red blood cells, then passed through a $40 \mu \mathrm{m}$ strainer to obtain a single-cell suspension.

Cell activation analysis: after preparing spleen single-cell suspensions, cells were immediately analyzed for activation markers. Cells were blocked by Fc-receptor blockade with anti-CD16/CD32 (BD Biosciences), and then stained for 30 minutes at $4^{\circ} \mathrm{C}$ with the following antibody panel each diluted in PBS: APC/Cyanine7 anti-mouse CD45 antibody (Biolegend) or FITC anti-mouse CD45.2 antibody (Biolegend), APC anti-mouse CD4 antibody (Biolegend), APC/Cyanine7 anti-mouse CD19 antibody (Biolegend), PE anti-mouse CD8a antibody (Biolegend) or PE anti-mouse/human CD45R/B220 antibody (Biolegend), PerCP/Cyanine5.5 anti-mouse/human CD44 antibody (Biolegend), APC anti-mouse CD138 (Syndecan-1) antibody (Biolegend), Brilliant Violet 510 ${ }^{\mathrm{TM}}$ anti-mouse CD62L antibody (Biolegend), FITC anti-mouse CD107a (LAMP-1) antibody (Biolegend), APC/Cyanine7 anti-mouse CD19 antibody (Biolegend). Samples were analyzed on the CytoFLEX LX flow cytometer (Beckman Coulter). 


\section{ELISPOT}

IL-4 and IL-2 ELISPOT assays were performed with mouse IL-4 ELISPOT ${ }^{\text {PLUS }}$ kits

615 and mouse IL-2 ELISPOT ${ }^{\text {PLUS }}$ kits according to the manufacturer's instructions 
619 S peptide mix (Sino Biological) $(0.1 \mu \mathrm{g} / \mathrm{mL}$ final concentration per peptide). After 620 incubation at $37^{\circ} \mathrm{C}, 5 \% \mathrm{CO}_{2}$ for $18 \mathrm{~h}$, the plates were washed, and biotinylated antimouse IFN- $\gamma$, IL-2, or IL-4 antibody was added to each well, following incubation of 622 detection second antibodies. The air-dried plates were read using the automated

623

624 625 626

627

ELISPOT reader (Mabtech IRIS FluoroSpot/ELISpot reader) for calculating spotforming cells.

\section{Analysis of viral load by RT-qPCR}

Viral RNA in lung tissues from challenged hamsters was quantified by one-step realtime RT-PCR as described before (Feng et al., 2020). Briefly, viral RNA was purified using the QIAamp Viral RNA Mini Kit (Qiagen), and quantified with HiScript ${ }^{\circledR}$ II One Step qRT-PCR SYBR ${ }^{\circledR}$ Green Kit (Vazyme Biotech) with the primers ORF1ab-F (5'CCCTGTGGGTTTACACTTAA-3') and ORF1ab-R

ACGATTGTGCATCAGCTGA-3'). The amplification procedure was set up as: $50^{\circ} \mathrm{C}$ for $3 \mathrm{~min}, 95^{\circ} \mathrm{C}$ for $30 \mathrm{~s}$ followed by 40 cycles consisting of $95^{\circ} \mathrm{C}$ for $10 \mathrm{~s}, 60^{\circ} \mathrm{C}$ for 30 s.

\section{Analysis of viral load by plaque assay}

Virus titer was determined with plaque assay as previously described with slight modification (Zhang et al., 2020). Briefly, virus samples were serially 10-fold diluted with DMEM with 2.5\% FBS, and inoculated to Vero cells or Vero E6 seeded overnight at $1.5 \times 10^{5} /$ well in 24 -well plates; after incubated at $37^{\circ} \mathrm{C}$ for $1 \mathrm{~h}$, the inoculate was 
bioRxiv preprint doi: https://doi.org/10.1101/2022.03.01.481391; this version posted March 1, 2022. The copyright holder for this preprint (which was not certified by peer review) is the author/funder, who has granted bioRxiv a license to display the preprint in perpetuity. It is made available under aCC-BY-NC-ND 4.0 International license.

641 replaced with DMEM containing 2.5\% FBS and 0.9\% carboxymethyl-cellulose. The

642 plates were fixed with $8 \%$ paraformaldehyde and stained with $0.5 \%$ crystal violet 3

643 days later. Virus titer was calculated with the dilution gradient with 10 100 plaques.

644 Plaque assays were performed in a BSL3 facility with strict adherence to institutional 645 regulations.

646 
bioRxiv preprint doi: https://doi.org/10.1101/2022.03.01.481391· this version posted March 1, 2022. The copyright holder for this preprint (which was not certified by peer review) is the author/funder, who has granted bioRxiv a license to display the preprint in perpetuity. It is made available under aCC-BY-NC-ND 4.0 International license.

\section{QUANTIFICATION AND STATISTICAL ANALYSIS}

648 All data were analyzed with GraphPad Prism 8.0 software. No statistical methods were

649 used to predetermine sample size, unless indicated. Unless specified, data are presented

650 as mean \pm SEM in all experiments. Analysis of variance (ANOVA) or t-test was used

651 to determine statistical significance among different groups $(* p<0.05 ; * * p<0.01$;

652

$* * * \mathrm{p}<0.001 ; * * * * \mathrm{p}<0.0001)$

653 
654

655

656

657

658

659

660

661

662

663

664

665

666

667

668

669

670

671

672

673

674

675

676

677

678

679

680

681

\section{SUPPLYMENTRY TABLES AND FIGURES}

\section{Table S1}

Amino Acid Sequence Alignment of the Full S Protein of Somicron-6P. MFVFLVLLPLVSSQCVNLTTRTQLPPAYTNSFTRGVYYPDKVFRSSVLHSTQDL FLPFFSNVTWFHVISGTNGTKRFDNPVLPFNDGVYFASIEKSNIIRGWIFGTTLD SKTQSLLIVNNATNVVIKVCEFQFCNDPFLDHKNNKSWMESEFRVYSSANNC TFEYVSQPFLMDLEGKQGNFKNLREFVFKNIDGYFKIYSKHTPIIVRDLPQGFS ALEPLVDLPIGINITRFQTLLALHRSYLTPGDSSSGWTAGAAAYYVGYLQPRTF LLKYNENGTITDAVDCALDPLSETKCTLKSFTVEKGIYQTSNFRVQPTESIVRF PNITNLCPFDEVFNATRFASVYAWNRKRISNCVADYSVLYNLAPFFTFKCYGVS PTKLNDLCFTNVYADSFVIRGDEVRQIAPGQTGNIADYNYKLPDDFTGCVIAW NSNKLDSKVSGNYNYLYRLFRKSNLKPFERDISTEIYQAGNKPCNGVAGFNCY FPLRSYSFRPTYGVGHQPYRVVVLSFELLHAPATVCGPKKSTNLVKNKCVNFN FNGLKGTGVLTESNKKFLPFQQFGRDIADTTDAVRDPQTLEILDITPCSFGGVS VITPGTNTSNQVAVLYQGVNCTEVPVAIHADQLTPTWRVYSTGSNVFQTRAGC LIGAEYVNNSYECDIPIGAGICASYQTQTKSHRRARSVASQSIIAYTMSLGAEN SVAYSNNSIAIPTNFTISVTTEILPVSMTKTSVDCTMYICGDSTECSNLLLQYGS FCTQLKRALTGIAVEQDKNTQEVFAQVKQIYKTPPIKYFGGFNFSQILPDPSKPS KRSPIEDLLFNKVTLADAGFIKQYGDCLGDIAARDLICAQKFKGLTVLPPLLTD EMIAQYTSALLAGTITSGWTFGAGPALQIPFPMQMAYRFNGIGVTQNVLYENQ KLIANQFNSAIGKIQDSLSSTPSALGKLQDVVNHNAQALNTLVKQLSSKFGAIS SVLNDIFSRLDPPEAEVQIDRLITGRLQSLQTYVTQQLIRAAEIRASANLAATK MSECVLGQSKRVDFCGKGYHLMSFPQSAPHGVVFLHVTYVPAQEKNFTTAPA ICHDGKAHFPREGVFVSNGTHWFVTQRNFYEPQIITTDNTFVSGNCDVVIGIV NNTVYDPLQPELDSFKEELDKYFKNHTSPDVDLGDISGINASVVNIQKEIDRL NEVAKNLNESLIDLQELGKYEQYIKWPWYIWLGFIAGLIAIVMVTIMLCCMTS CCSCLKGCCSCGSCCKFDEDDSEPVLKGVKLHYT 
682

683

684

685

686

687

688

689

691

690 encapsulated with SOmicron-6P mRNA. Data are shown as mean \pm SD.

B

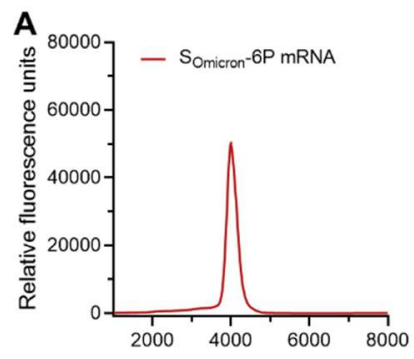

Size (nt)
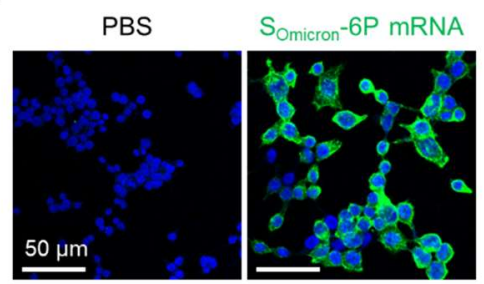

C

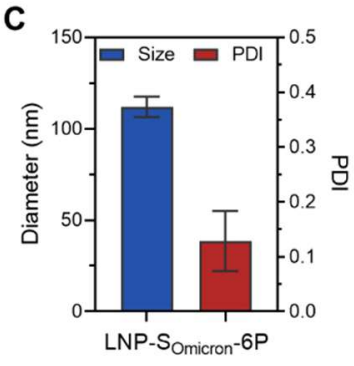

\section{Figure S1. SARS-CoV-2 Omicron mRNA Vaccine Design and Characterization,}

\section{Related to Figures 1-4}

(A) Liquid capillary electropherograms of in vitro-transcribed S Somicron-6P mRNA.

Peaks represent individual samples merged into one graph.

(B) Immunofluorescence analysis of the expression of Omicron spike protein in HEK293T cells.

(C) Sizes and polydispersity index (PDI) values of lipid nanoparticles (LNP) 

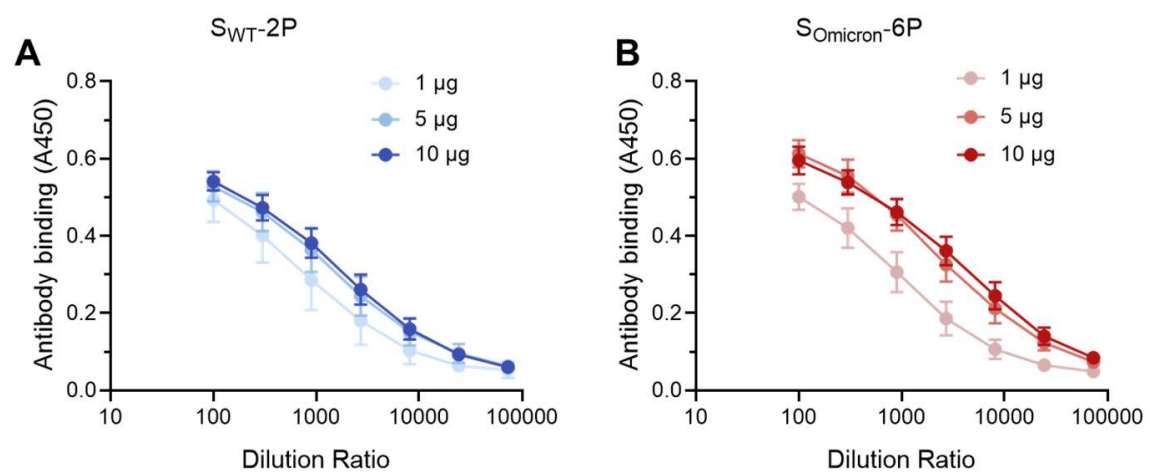

693 Figure S2. Somicron-6P or SwT-2P Elicited Binding Antibodies in Mice, Related to

694 Figure 1

695 (A-B) ELISA binding curves of (A) $\mathrm{S}_{\mathrm{WT}}-2 \mathrm{P}$ or (B) SOmicron-6P induced binding 696 antibodies in mouse sera.

697 
698

699

700

701

702

703
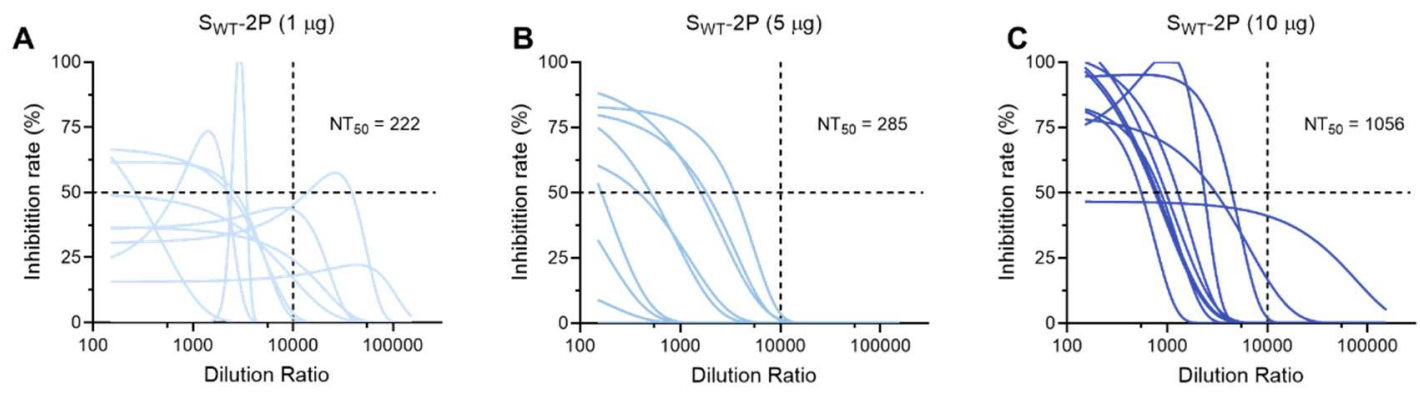

Figure S3. SwT-2P Induced Low Levels of nAbs Against SARS-CoV-2 Omicron Variant in Mice, Related to Figure 1

(A-C) Neutralization curves of (A) 1, (B) 5, and (C) $10 \mu \mathrm{g} \mathrm{S} \mathrm{ST}_{\mathrm{W}}-2 \mathrm{P}$ induced antibodies against pseudotyped and replication-deficient SARS-CoV-2 Omicron. 
704
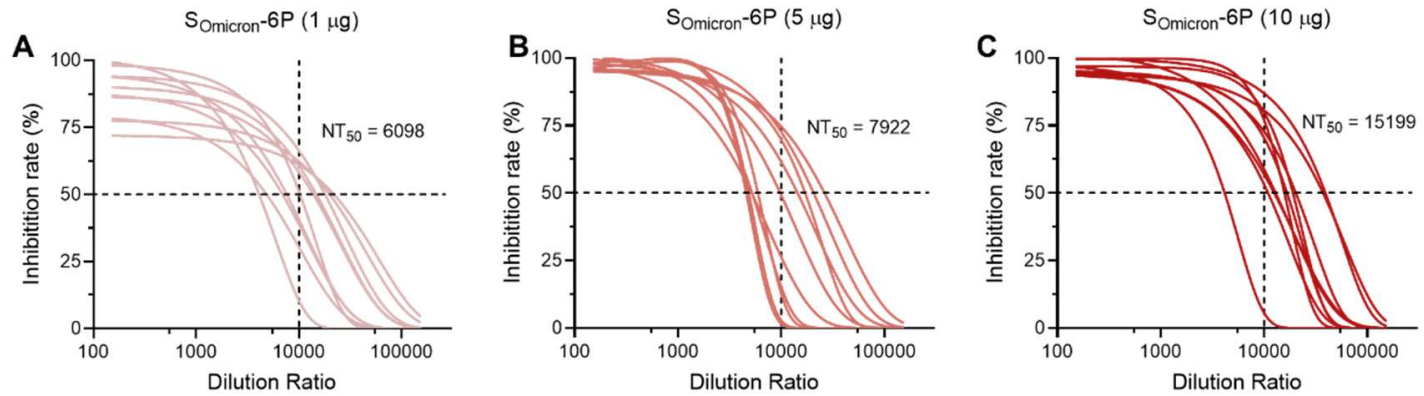

\section{Figure S4. Somicron-6P Induced High Levels of nAbs Against SARS-CoV-2 Omicron}

\section{Variant in Mice, Related to Figure 1}

709 

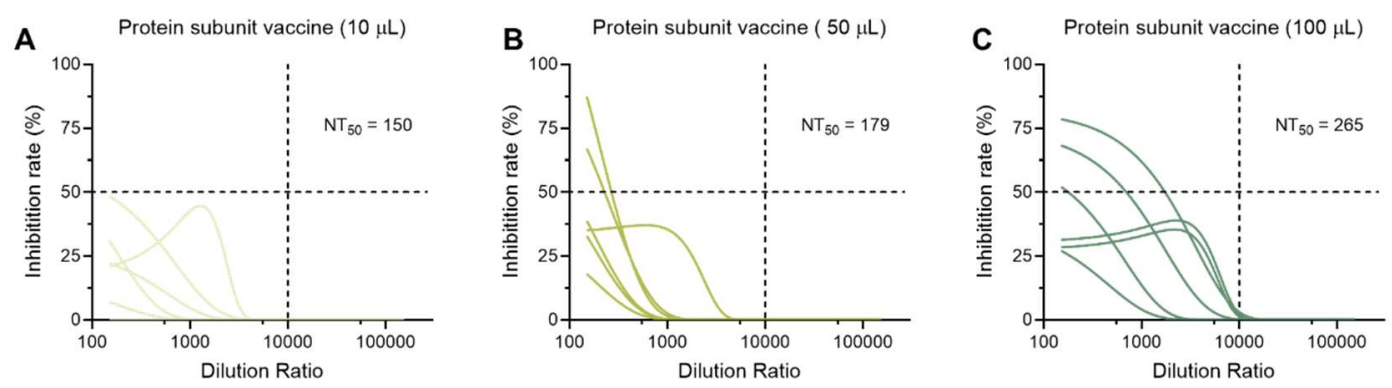

711 Figure S5. Clinically Approved Protein Subunit Vaccine Rarely Induced nAbs

713 (A-C) Neutralization curves of (A) 10, (B) 50, and (C) $100 \mu \mathrm{L}$ protein subunit vaccine

$714(500 \mu \mathrm{L} /$ vial for an adult) induced antibodies against pseudotyped and replicationdeficient SARS-CoV-2 Omicron. 

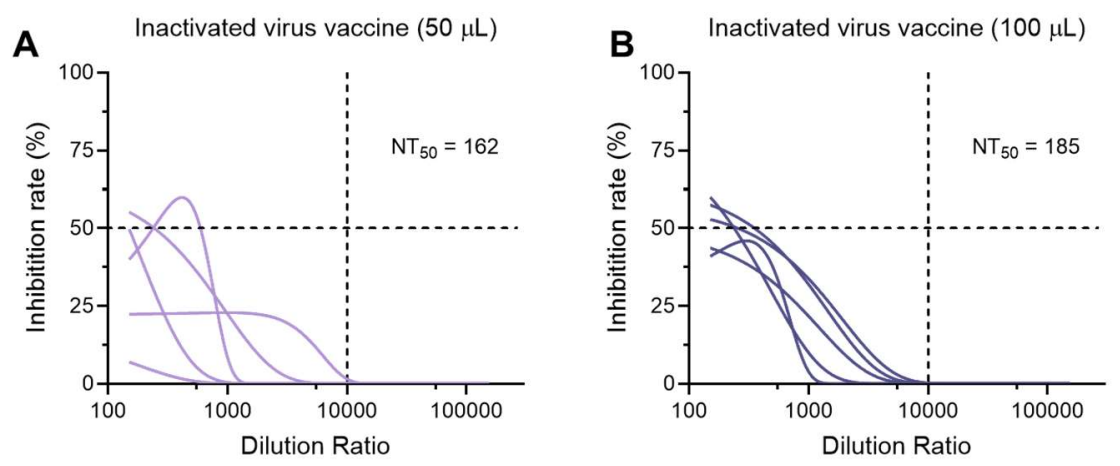

718 Figure S6. Clinically Approved Inactivated Virus Vaccine Rarely Induced nAbs

719 Against SARS-CoV-2 Omicron Variant in Mice, Related to Figure 1

720 (A-B) Neutralization curves of (A) 50, and (B) $100 \mu \mathrm{L}$ inactivated virus vaccine (500

$721 \mu \mathrm{L} /$ vial for an adult) induced antibodies against pseudotyped and replication-deficient

722 SARS-CoV-2 Omicron.

723 
A

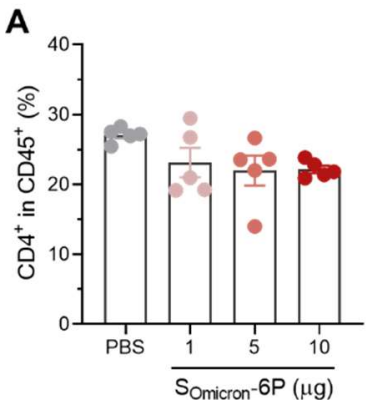

B

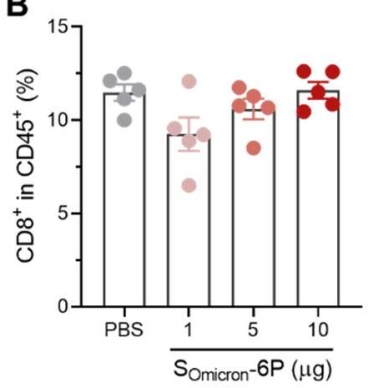

727 Figure S7. The Percentages of $\mathrm{CD4}^{+}$and $\mathrm{CD8}^{+} \mathrm{T}$ Cells Among Lymphocytes in 728 Spleen, Related to Figure 2

729 Female BALB/c mice were immunized with $0,1,5$ or $10 \mu \mathrm{g}$ Somicron-6P. Twenty-nine 730 days after the first immunization, mice were euthanized and their spleens were collected 731 for $\mathrm{T}$ cell response and phenotyping analysis.

732 (A-B) The percentages of (A) $\mathrm{CD}^{+}$and (B) $\mathrm{CD}^{+} \mathrm{T}$ cells among lymphocytes in spleen. 


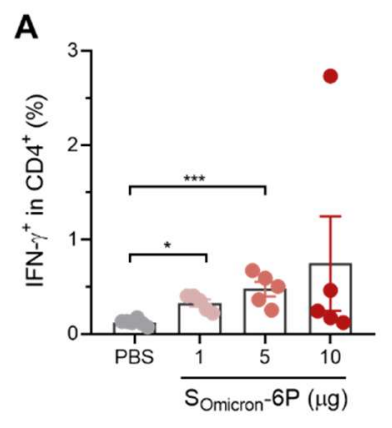

D

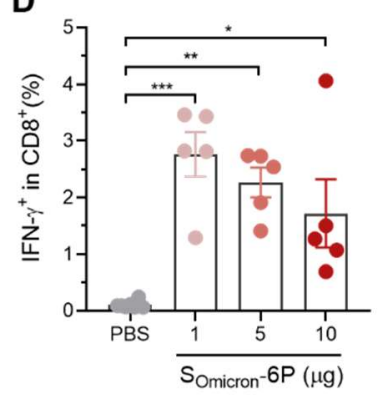

B

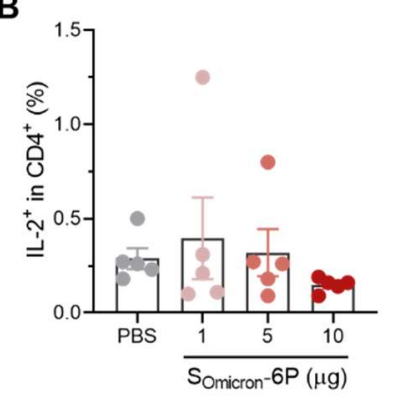

E

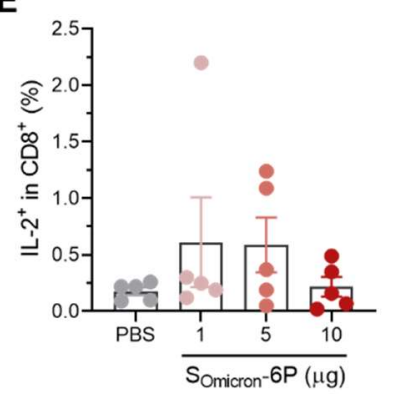

C

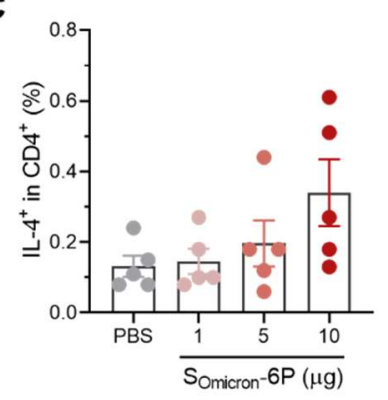

734

735

736

737

738

739

740

741

742

743

744

745

Figure S8. T Cell Intracellular-Cytokine Analysis of Somicron-6P Immunized Mice,

\section{Related to Figure 2}

Splenocytes of mice receiving different immunizations were ex vivo re-stimulated with full-length S peptide mix or cell culture medium. Flow cytometry analysis of the percentages of IFN- $\gamma^{+}, \mathrm{IL}_{-} 2^{+}$, and $\mathrm{IL}-4^{+}$among $\mathrm{CD} 4^{+}$and $\mathrm{CD} 8^{+} \mathrm{T}$ cells.

(A-C) Flow cytometry analysis of the percentages of (A) IFN- $\gamma^{+},(B) \mathrm{IL}^{+} 2^{+}$, and (C) IL$4^{+}$among $\mathrm{CD}^{+} \mathrm{T}$ cells.

(D-E) The percentages of (D) IFN- $\gamma^{+}$, and (E) IL-2 ${ }^{+}$among $\mathrm{CD} 8^{+} \mathrm{T}$ cells.

Data are shown as mean \pm SEM. Significance was calculated using one-way ANOVA with multiple comparisons tests $\left(* \mathrm{p}<0.05,{ }^{*} \mathrm{p}<0.01,{ }^{* * *} \mathrm{p}<0.001\right)$ 

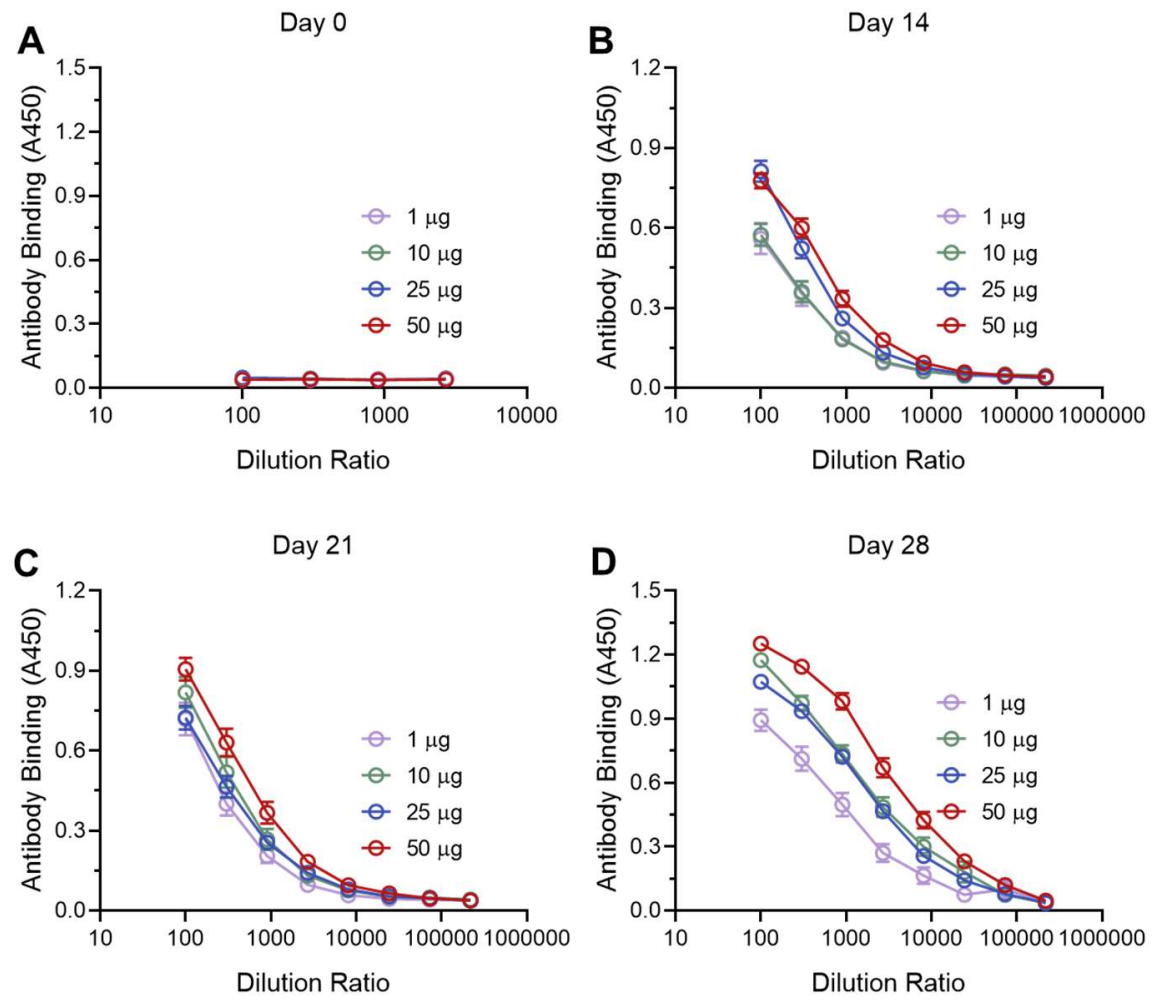

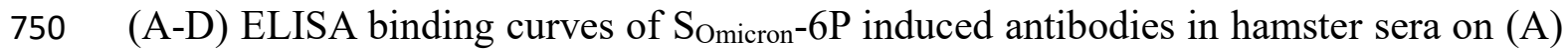
day $0,(\mathrm{~B})$ day $14,(\mathrm{C})$ day 21 , and (D) day 28. 

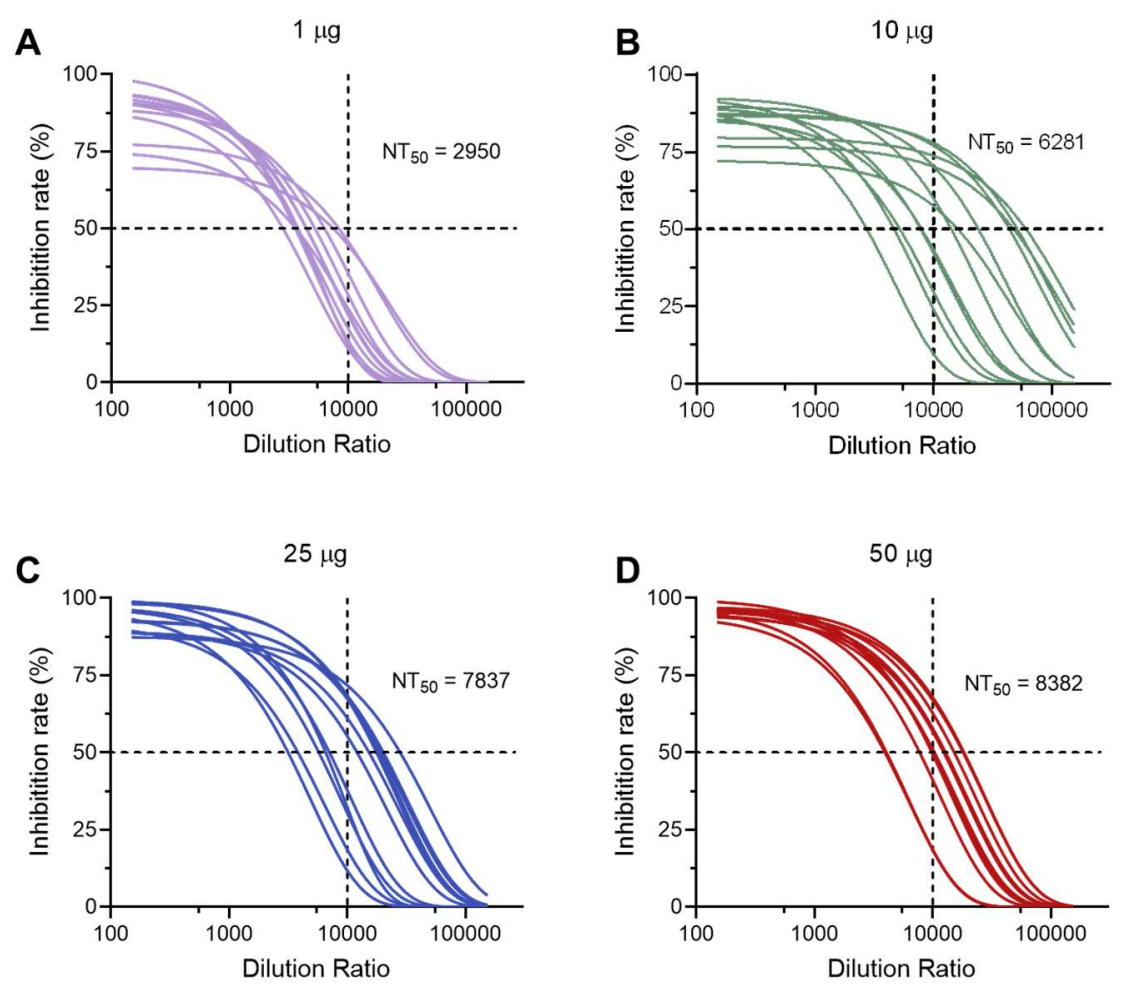

754 Figure S10. Somicron-6P Induced High Levels of nAbs Against SARS-CoV-2

755 Omicron Variant in Hamsters, Related to Figure 3

756 (A-D) Neutralization curves of (A)1, (B) 10, (C) 25, and (D) $50 \mu \mathrm{g}$ S Omicron-6P induced 757 antibodies against pseudotyped and replication-deficient SARS-CoV-2 Omicron at 1 758 week after second vaccination. 

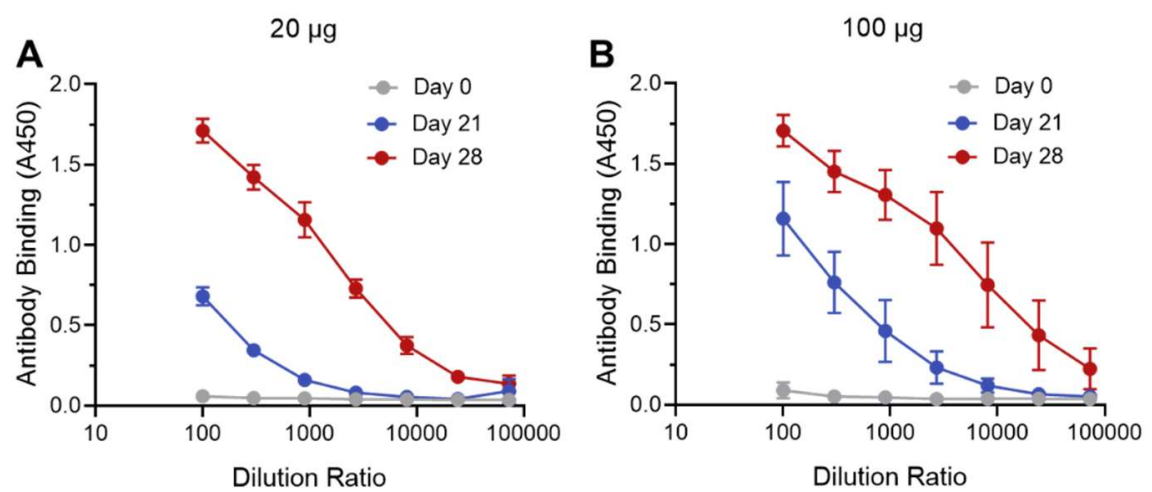

762 Figure S11. Somicron-6P Elicited Binding Antibodies in Macaques, Related to Figure

763 4

(A-B) ELISA binding curves of (A) 20 and (B) $100 \mu \mathrm{g}$ Somicron-6P induced antibodies

765 in macaque sera on day $0,21,28$ after the first immunization. 

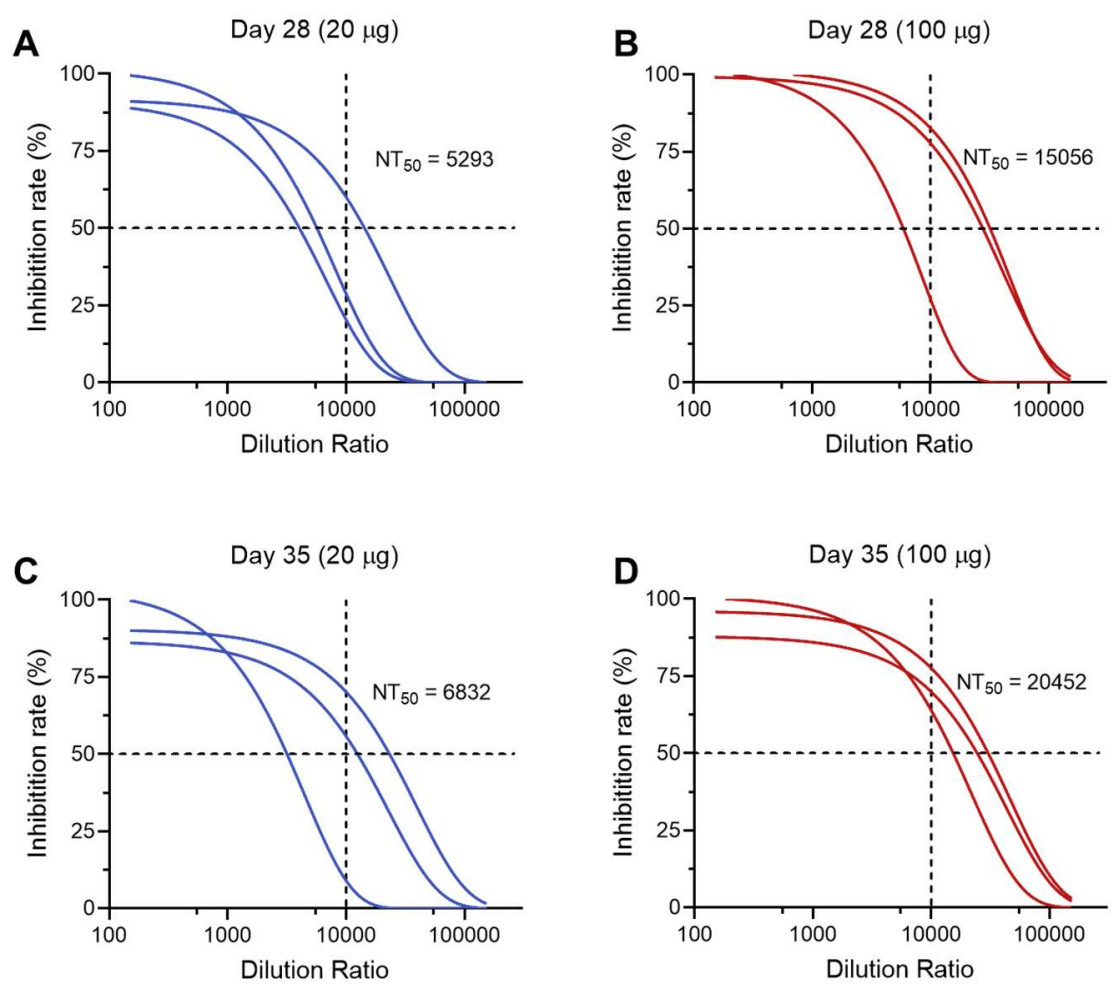

768 Figure S12. Somicron-6P Induced High Levels of nAbs Against SARS-CoV-2

769 Omicron Variant in Macaques, Related to Figure 4

770 (A-D) Neutralization curves of $\mathrm{S}_{\text {Omicron-6P induced antibodies against pseudotyped and }}$ 771 replication-deficient SARS-CoV-2 Omicron (A and B) 1 week and (C and D) 2 weeks 772 after the second vaccination. 